Recreation Management Support Program

\title{
Economic Impacts from Spending by Private Dock Owners at Lake Barkley
}

Richard Kasul, LiChu Lee, Kathleen Perales, Dennis B. Propst,

February 2008

Benoni L. Amsden, and Wen-Huei Chang 


\section{Economic Impacts from Spending by Private Dock Owners at Lake Barkley}

Richard Kasul, LiChu Lee, Kathleen Perales, and Wen-Huei Chang

Environmental Laboratory

U.S. Army Engineer Research and Development Center

3909 Halls Ferry Road

Vicksburg, MS 39180-6199

Dennis B. Propst and Benoni L. Amsden

Michigan State University

115 Natural Resources Building

East Lansing, MI 48824

Final report

Approved for public release; distribution is unlimited.

Prepared for U.S. Army Corps of Engineers

Washington, DC 20314-1000 


\begin{abstract}
This report documents the local economic impacts of private dock users at Lake Barkley, located on the border of Kentucky and Tennessee. This economic assessment is based on the results of a 1999 survey of a sample of Lake Barkley private dock owners. Spending estimates are adjusted to 2004 dollars. The economic impacts estimated for Lake Barkley are useful for accountability purposes, lake support, and explaining the role of the lake in the region's economy. This report demonstrates how the survey results can also be used to evaluate management alternatives and strategies and to conduct sensitivity analyses.
\end{abstract}

DISCLAIMER: The contents of this report are not to be used for advertising, publication, or promotional purposes. Citation of trade names does not constitute an official endorsement or approval of the use of such commercial products. All product names and trademarks cited are the property of their respective owners. The findings of this report are not to be construed as an official Department of the Army position unless so designated by other authorized documents. 


\section{Contents}

Figures and Tables................................................................................................................

Summary

Foreword .....................................................................................................................................................viii

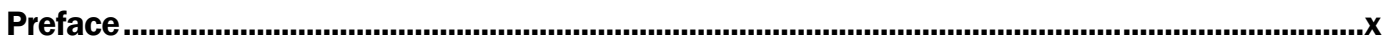

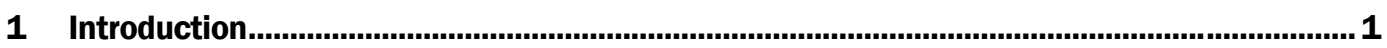

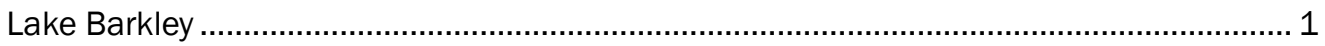

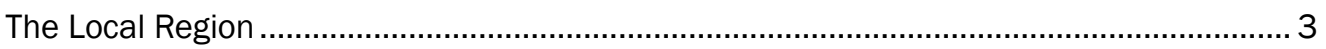

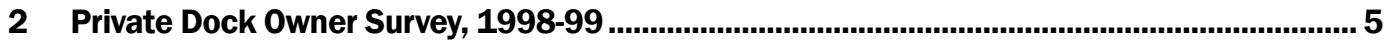

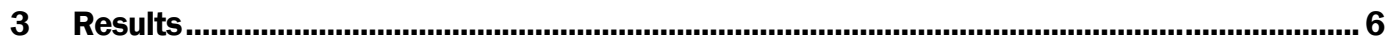

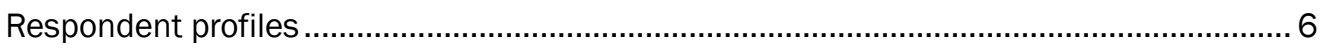

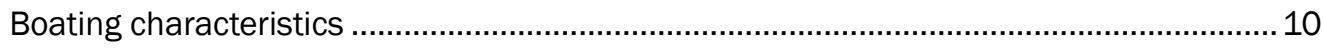

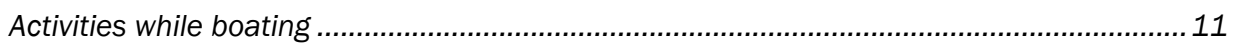

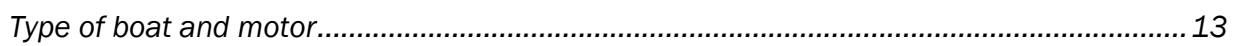

Dock user segments and spending........................................................................ 14

Average spending for full sample of dock owners ...................................................... 14

Average spending by segment: Day use vs. overnight................................................... 17

Average spending by boat length segments.................................................................. 17

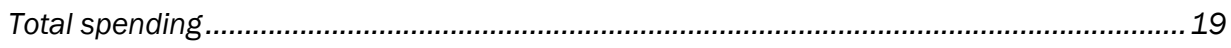

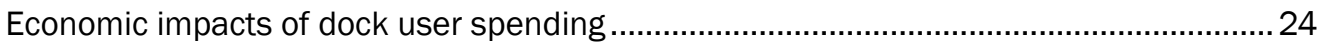

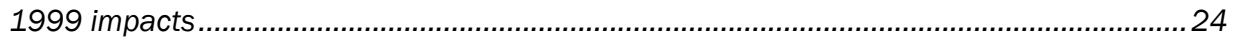

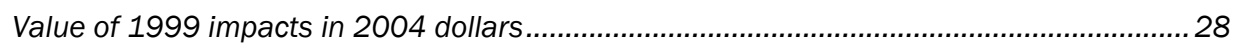

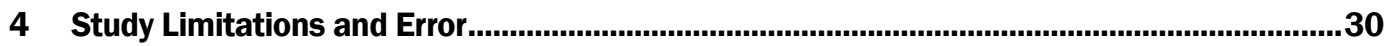

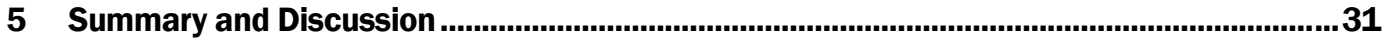

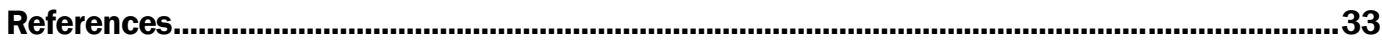

\section{Report Documentation Page}




\section{Figures and Tables}

\section{Figures}

Figure 1. Lake Barkley and the surrounding region.

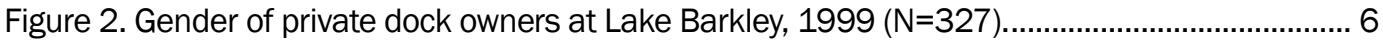

Figure 3. Age of private dock owners at Lake Barkley, $1999(\mathrm{~N}=324)$............................................. 7

Figure 4. Education of private dock owners at Lake Barkley, $1999(\mathrm{~N}=325)$................................. 7

Figure 5. Race of private dock owners at Lake Barkley, $1999(\mathrm{~N}=325)$ (about 1 percent were Hispanic or of Latino origin) . ............................................................................................ 7

Figure 6. Survey conducted with registered boat owners at Lake Barkley private docks,

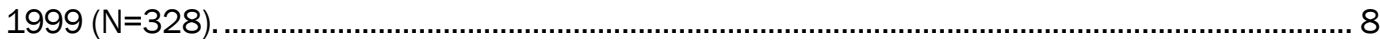

Figure 7. Household income of private dock owners at Lake Barkley, $1999(\mathrm{~N}=286)$..................... 8

Figure 8. Household size of private dock owners at Lake Barkley, 1999 ( $\mathrm{N}=320)$........................... 9

Figure 9. Number of people under 18 in households of private dock owners at Lake

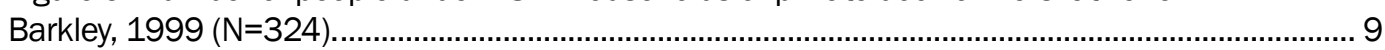

Figure 10. Permanent residence of private dock owners at Lake Barkley, $1999(\mathrm{~N}=328)$.............. 10

Figure 11. Seasonal home ownership of private dock owners at Lake Barkley, 1999 $(\mathrm{N}=328)$.

Figure 12. Number of boating trips made by private dock owners last year compared to previous 3-year average at Lake Barkley, 1999 ( $N=294)$.

Figure 13. "What other activities did you or others participate in during your boating trips last year that I have not already mentioned?" (from Lake Barkley Private Docks, 1999, $\mathrm{N}=270$ ).

Figure 14. Expenditures by private dock owners/users on most recent trip compared to similar trips in the last 12 months at Lake Barkley, 1999 ( $N=307)$.

\section{Tables}

Table 1. Summary of recreation visits to Lake Barkley, 1999 3

Table 2. Economic activity in the Lake Barkley region, 2000.

Table 3. Trips to Lake Barkley private boat docks the previous year (09/01/1998 to 08/31/1999).

Table 4. Recreation activity participation during previous year's trips to Lake Barkley private boat docks (09/01/1998 to 08/31/1999).

Table 5. Boat type and length cross-tabulation, Lake Barkley private dock owner survey, $1999(\mathrm{~N}=278)$.

Table 6. Boat type and motor cross-tabulation, Lake Barkley private dock owner survey, 1999 ( N = 257).

Table 7. Boat length and motor cross-tabulation, Lake Barkley private dock owner survey, $1999(\mathrm{~N}=250)$.

Table 8. Summary of Lake Barkley private dock owners'/users' spending and use profiles, 09/1998 to 08/1999 (spending per party trip). 
Table 9. Spending and use by length of stay segments, Lake Barkley private dock owner survey, 09/1998 to 08/1999 (spending per party trip).

Table 10. Spending and use by boat length segments, Lake Barkley private dock owner survey, 09/1998 to 08/1999, (spending per party trip).

Table 11. Total annual use figures for private dock owner survey at Lake Barkley (1999).

Table 12. Total trip spending in local area by Lake Barkley private dock owners/users (1999).

Table 13. Total trip spending by Lake Barkley private dock owners/users (1999).....

Table 14. Total spending on fixed, annual goods and services by private dock owners at Lake Barkley (1999).

Table 15. Regional economic impacts of Lake Barkley private dock owners'/users' trip spending (1999, for trip spending within 30 miles only).

Table 16. Regional economic impacts of Lake Barkley private dock owners' durable goods and annual spending (1999).

Table 17. Regional economic impacts of Lake Barkley private dock owners'/users' trip and owners' annual spending (in 2004 dollars, for spending within 30 miles only)...

Table 18. Direct impacts of an additional 1,000 private dock owner party trips by segment, Lake Barkley. 


\section{Summary}

This report documents the local economic impacts of private dock owners and guests at Lake Barkley, located on the border of Kentucky and Tennessee and situated within the U.S. Army Corps of Engineers District, Nashville. This economic assessment is based on the results of a 1999 survey of a sample of Lake Barkley private dock owners. Spending estimates are adjusted to 2004 dollars.

Lake Barkley, its western counterpart, Kentucky Lake and the area between the two create a significant land and water resource that has become a popular tourist destination, called Land Between the Lakes (LBL). Managed by the USDA Forest Service as a National Recreation Area, LBL attracts more than 2 million visitors annually from all over the United States and the world.

Total tourism activity in the 15-county region surrounding Lake Barkley is about $\$ 568$ million, or 2.2 percent of all economic activity in that region. Lake Barkley is 134 miles long, covers 57,900 surface acres at summer pool, and boasts over 1004 miles of shoreline. Access to large bodies of water and their related resources, including scenic views, make these lakes desirable for the location of private homes and associated private boat docks. The Corps of Engineers permitted nearly 1,00o private boat docks at Lake Barkley in 1999. The estimated 51, 237 party trips taken by private boat dock owners/users in 1999 accounted for 3.7 percent of total recreation usage at the lake.

In 1999, private dock owners/users spent significant amounts of money in the local area, including $\$ 7.3$ million on trip-related items (gasoline, meals, lodging, etc.) and $\$ 1.3$ million on new boats, insurance, dock maintenance and other annual services. Together, this $\$ 8.6$ million in spending in the 15-county region surrounding Lake Barkley provides the economic base for $\$ 5$ million in direct sales, $\$ 2$ million in direct wages for local residents and 115 jobs in area tourism-related businesses. The $\$ 5$ million in direct sales is about 0.9 percent of the total of all tourism activity ( $\$ 568$ million) (sales have been price inflated for this computation). In 2004 dollars, these figures become $\$ 8.81$ million in trip-related expenditures and $\$ 1.61$ million in new boats and annual expenses. The added economic 
effects-in 2004 dollars-are \$6 million in direct sales and \$2.4 million in direct personal income.

The figures above are direct effects only of the $\$ 8.6$ million in dock owner/user spending in 1999. Another \$2.4 million in sales (\$2.9 million in sales in 2004 dollars) is generated through secondary effects, as dock owner/user spending circulates through the local economy. While the direct effects accrue primarily to the retail trade sector, restaurants, manufacturing (mainly because of the purchases of new boats locally), and services, secondary effects benefit a wide range of local businesses. The tourism sales multiplier for the region is 1.46 indicating there is $\$ 0.46$ in secondary sales for every dollar of direct sales.

Visitor segmentation is useful for planning purposes. This report provides results for the full sample of private dock owners/users and for dock owner segments that are useful for planning purposes: day use vs. overnight stay dock owners and dock owners in three boat size classes. Day users comprised 62 percent of the sample of dock users, while 38 percent spent at least one night in the area on their last trip. In terms of total spending in the local region, day users of private docks contributed 46 percent and overnight stay dock users, 54 percent. One-third of the sample had small-sized boats ( $17 \mathrm{ft}$ and smaller), while 42 percent were medium (18 to $23 \mathrm{ft}$ ) and 27 percent were large (above $23 \mathrm{ft}$ ). Dock users with large boats contributed 23 percent of total spending locally, dock users with medium-sized boats, 46 percent, and those with small boats, 31 percent.

The economic impacts estimated for Lake Barkley are useful for accountability purposes, lake support, and explaining the role of the lake in the region's economy. This report demonstrates how the results can also be used to evaluate management alternatives and strategies and to conduct sensitivity analyses. 


\section{Foreword}

This report represents one of nine market segmentation studies conducted at Corps of Engineers (Corps) water resources projects (lakes). The economic impact studies were conducted in 1999 and the information has been converted to 2004 dollars. It should be noted that no single study provides a complete portrait of any lake's boating market. The studies were limited to three market segments: marina slip renters, private dock, and community dock owners. These three groups do not reflect the spectrum of boating usage or market segments at any one of the lakes studied. The primary purpose of the studies was to obtain an understanding of these three market segments.

In addition to recreation usage, each of these segments is handled under different real estate instruments or shoreline use permit instruments. Marina slips (one boat per slip) are handled by the Corps at the marina facility level. Individual marina operators (lease holders) were involved in the development of contact lists for individual slip renters. Private dock owners (one dock permit, one household, potentially multiple boats) have a direct shoreline-use permit with the Corps and pay a fee. Community docks (one dock permit, multiple households, one boat per slip, a single household may hold multiple slips) are not tied to a single household but to a group of homes within a community. This permit type has a single point of contact (e.g. homeowner association). Typically the fee for a private or community dock permit is between $\$ 30$ and $\$ 35$ for 5 years. Additional administrative fees may also be collected to recover the cost of administration inspections and processing of permits; this cost is variable.

The lakes and market segments studied were:

- Table Rock Lake, community dock

- Rough River Lake, community dock

- Pomme de Terre Lake, community dock

- Harry S. Truman Dam and Reservoir, marina

- Raystown Lake, marina

- Hartwell Lake, private dock

- Lake Barkley, private dock

- Lake Sidney Lanier, private dock and marina 
Each of the lakes studied has a variety of boating and water usage issues that were not a part of this economic impact evaluation. This economic impact assessed recreation visitor trip spending and annual durable goods-related expenditures. In order to provide managers with a tool to assess the effects of management, this report outlined the spending categories of boat owners and visitors associated with the recreational trip under study. Examples are provided illustrating changes in the number of boat trips and the changes that could be seen in economic impacts. These are provided as illustrations. The same illustration can be used by managers to help assess low water conditions and boating trips lost, to get a sense of the change in economic impacts. This study did not include the impacts of additional boats over time to determine changes in use, water quality, social or environmental impacts, or the like. This study did not include changes in use based on increases in gasoline prices or technological changes in boating products. These are elements outside the study parameters and would serve as useful points of departure for further research. These reports should be evaluated in part with the larger boating usage that occurs at the individual lake and the changes that have occurred over time (including expenditure changes such as the increasing cost of gasoline). They serve in part to document a baseline, which in part justifies publication at this late date.

For example, at a single lake, boating utilization should be evaluated within a larger context of the multipurpose mission of each of the lakes. To get an understanding of historical use and issues at Corps of Engineers facilities, the following documents have been recommended for further study: national and state regulations, project master-planning documents, shoreline management plans, environmental assessments, and other local studies. Consult the local project manager for an assessment of other documents that should be considered in addition to the ones provided. 


\section{Preface}

The work reported herein was undertaken for the "Measuring the Economic Effects of Boat Dock Permit and Marina Slip Holders" work unit of the Recreation Management Support Program (RMSP). The RMSP is funded by the Operations and Maintenance (O\&M) General Appropriation and encompasses activities previously conducted through the Recreation Research Program and the Natural Resources Technical Support Program. The U.S. Army Engineer Research and Development Center (ERDC) provides program management support for execution of approved RMSP activities. The RMSP is managed at ERDC by Scott Jackson, Environmental Laboratory (EL). Kathleen Perales has served as Principal Investigator of the work unit since its creation in 1995.

This report documents a joint effort between ERDC and Michigan State University under contract with the United States Department of Agriculture to conduct lake level investigations on the economic spending patterns of visitors to communities, private boat docks, and marinas on Corps of Engineers water resources projects.

A Recreation Leadership Advisory Team (RLAT) provides oversight for the RMSP. The team has representatives from each Major Subordinate Command/Regional Office within the Corps of Engineers. In addition, four district offices and four project offices are represented. Donald Dunwoody, RLAT representative from the Northwestern Division, served as proponent for this work unit.

This report was prepared by Benoni Amsden and Dr. Dennis Propst of Michigan State University under USDA contract. Dr. Wen-Huei Chang, ERDC, performed all economic impact analyses. Dr. LiChu Lee, ERDC, served to verify all data elements. Richard Kasul, ERDC, and Kathleen Perales, ERDC, were responsible for the design, instrumentation, sampling frame, and contract oversight. This work was conducted under the general supervision of Scott Jackson, Acting Chief, Ecological Resources Branch (ERB); Dr. David Tazik, Chief, Ecosystem Evaluation and Engineering Division (EEED); and Dr. Beth Fleming, Director, EL. 
Peer reviewers of this report were Tim Dunn, Resource Manager, Center Hill Lake, Nashville District, USACE; Michael G Ensch, Chief, Operations Division, Nashville District, USACE; Dr. Michael A Loesch, Recreation and Environmental Stewardship Programs Manager, The Great Lakes and Ohio River Division, USACE; and Mr. Michael Looney, Resource Manager, Lake Barkley, USACE.

COL Richard B. Jenkins was Commander and Executive Director of ERDC. Dr. James R. Houston was Director. 


\section{Introduction}

This report documents the local economic impacts of private dock ${ }^{1}$ users at Lake Barkley, located on the border of Kentucky and Tennessee. These estimates are then adjusted to 2004 dollars. Economic impacts are measured as the direct and secondary sales, income, and jobs in the local area resulting from spending by those who use private docks. The economic estimates are produced using the Recreation Economic Assessment System (REAS) (Chang et al. 2001). Three major inputs to the model are:

- number of visits broken down into day use/overnight segments and three boat size segments

- spending averages for each segment

- economic multipliers for the local region

Inputs are derived from results contained in this report, the Natural Resource Management System (NRMS) database (U.S. Army Corps of Engineers (USACE 2006c)), and IMPLAN input-output modeling software (Minnesota IMPLAN Group 1996). The REAS model (USACE 2006a) provides a spreadsheet template for combining dock user visitation data, spending and regional multipliers to compute changes in sales, personal income, jobs, and value added in the region.

\section{Lake Barkley}

Lake Barkley is 134 miles long, covers 57,900 surface acres at summer pool, and boasts over 1004 miles of shoreline (Figure 1). Created for flood control and hydroelectric generation by the Army Corps of Engineers in 1966, the lake runs parallel to Kentucky Lake for over 50 miles. The Land Between the Lakes (LBL) recreation area is located between the two bodies of water, and is managed jointly by the U.S. Forest Service and the Tennessee Valley Authority (TVA) as a multi-use resource management demonstration area.

\footnotetext{
1 Private Docks: A private dock is one that serves only one property owner. These docks should be permitted under the authority of ER 1130-2-406 (USACE 1999). Do not include commercial docks or marinas.

Community Docks: Community docks are privately owned, multi-slip facilities shared and used by several groups of people. These docks should be permitted under the authority of ER 1130-2-406 (USACE 1999). Do not include commercial docks or marinas. (USACE 2006c).
} 


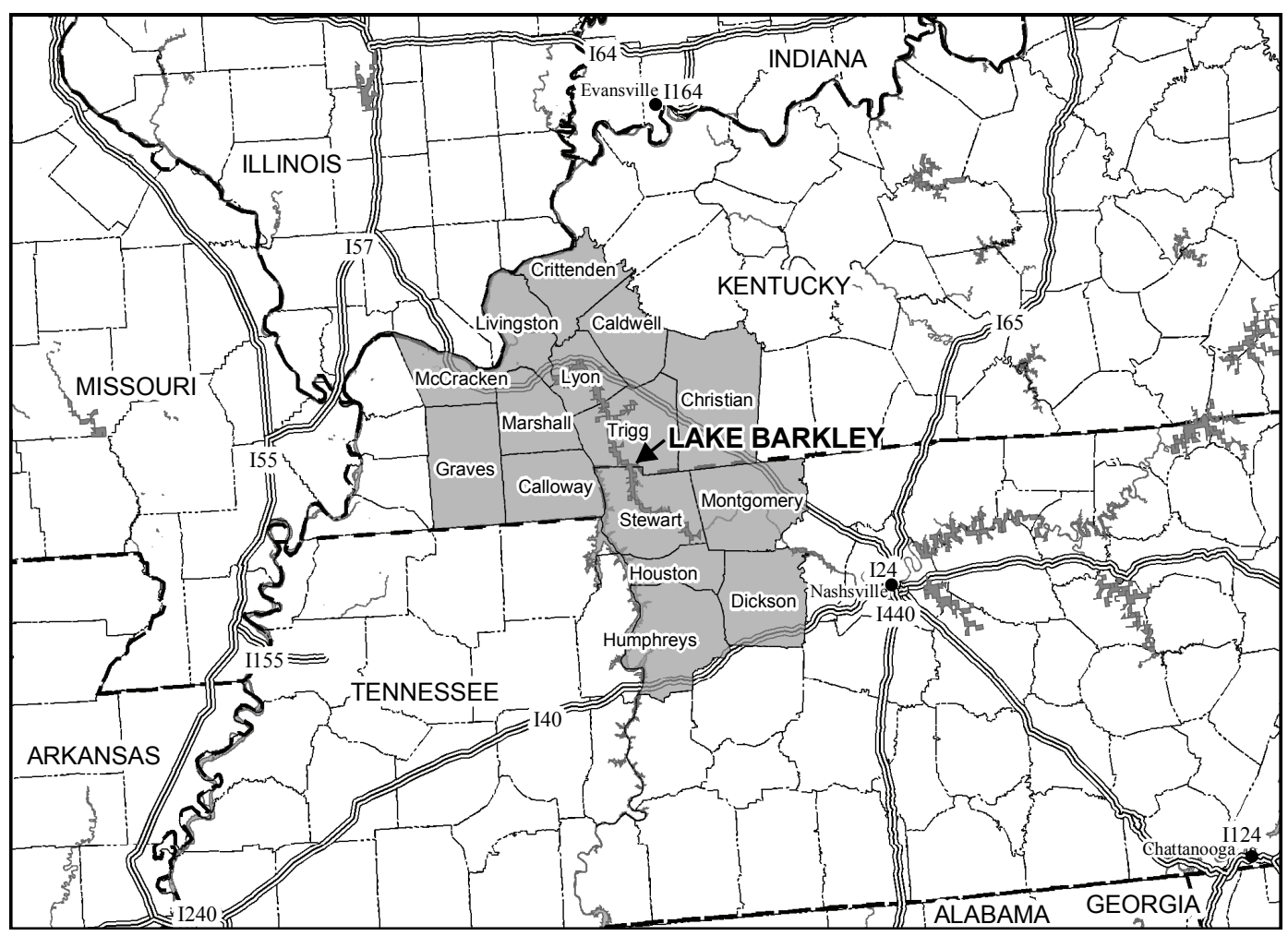

Figure 1. Lake Barkley and the surrounding region.

Lake Barkley (USACE 2006b) includes ten recreation areas and four campgrounds, providing hunting, fishing, nature trails and hiking, a national battlefield, and a waterfowl refuge. The LBL National Recreation Area (USDA Forest Service 2006) contains almost 300 miles of undeveloped shoreline and, with Lakes Barkley and Kentucky, contains more total shoreline than Lake Superior. LBL possesses 170,000 acres of forest, the second largest contiguous block of forested public land east of the Mississippi. In addition, the area includes 200 miles of hiking/biking trails, four developed campgrounds, a water park, several restaurants, and a museum. In sum, the LBL region, including Lakes Barkley and Kentucky, is a significant tourism destination, drawing over 2 million visitors annually from all 50 states and 30 foreign countries.

Lake Barkley hosted nearly 4.1 million recreation visits in 1999, 96 percent of which were by day users (Table 1, top row). Non-boaters accounted for 3.4 million day use visits, and boaters another 594 thousand. Since visitor spending and economic impacts in this report are based on party-days or nights, these figures are shown on the bottom row of Table 1. In 1999, there were roughly 1.6 million party-days of recreation use. 
Table 1. Summary of recreation visits to Lake Barkley, 1999.

\begin{tabular}{|c|c|c|c|c|c|c|c|}
\hline & \multicolumn{2}{|c|}{ Camper $^{1}$} & \multicolumn{2}{|c|}{ Day User² } & \multicolumn{2}{|c|}{ Other Overnight ${ }^{3}$} & \multirow[b]{2}{*}{ Total } \\
\hline & Boat & Non-Boat & Boat & Non-Boat & Boat & Non-Boat & \\
\hline Visits (person-trips, 1000s) & 5.7 & 32.4 & 594.1 & $3,366.7$ & 17.8 & 101.0 & $4,117.7$ \\
\hline Average length of stay (Days) & 4.2 & 3.8 & - & - & 2.4 & 3.0 & - \\
\hline Average party size & 3.5 & 2.8 & 2.8 & 2.8 & 3.3 & 2.5 & - \\
\hline Visits (party-days, 1000s) & 6.9 & 44.7 & 213.4 & $1,216.8$ & 13.2 & 122.5 & $1,617.5$ \\
\hline
\end{tabular}

1 Number of campers in party days was derived from the 1998 NRMS (USACE 2006c), CUR_FEE database (the last year that camper revenue data is available) by dividing total camping revenue by an average of $\$ 8.00$ per party day camping fee and expanding by the number of non-Corps managed campsites. The number of camper party-days was then adjusted to 1999 by multiplying the ratio of 1999 visits to 1998 visits from the PR_USE database. Then, party-days were converted to person-trips by the following formula: Number of campers in person-trips = number of party-days times average party size/average length of stay. Percent of boaters was obtained from the NRMS, PR_USE database. Party size and length of stay figures are based on the results of a national survey (Chang et al. 2003).

2 Number of day users in person-trips was derived from the 1999 NRMS (USACE 2006c), PR_USE database by subtracting camper visits from total visits. Then, number of day users in party-days = number of person-trips times average length of stay/ average party size. Percent of boaters was obtained from NRMS, PR_USE database.

3 Assumes that 3 percent of day users stayed overnight in lodging accommodations outside of project boundaries.

\section{The Local Region}

Fifteen counties in Kentucky and Tennessee comprise the local economic impact study region for Lake Barkley. ${ }^{1}$ According to the U.S. Census Bureau (2006), the population of this area is 508,345 (2000) or 517,917 (2004 estimate). The average median household income is $\$ 32,797$, compared to the two-state average median of $\$ 35,016$.

The Construction, Manufacturing, Other Services, and Government sectors are the principal economic base of the area, combining to account for 64 percent of sales, 60 percent of jobs, and 73 percent of compensation (wages) in the 15-county region (Table 2). An estimate of total tourism sales in the local region is $\$ 568$ million (Table 2: 100 percent of hotel/ motel +100 percent of amusement and recreation +25 percent of restaurant +25 percent of retail sales). ${ }^{2}$ Thus, tourism accounts for 2-3 percent

\footnotetext{
1 The local region consists of: Kentucky - Caldwell, Calloway, Christian, Crittenden, Graves, Livingston, Lyon, Marshall, McCracken, Trigg. Tennessee - Dickson, Houston, Humphreys, Montgomery, Stewart.

2 Independent Travel Industry Association and Kentucky Tourism Development Cabinet estimate of the economic impact of domestic travelers in the same region in 2001 was $\$ 595$ million. (See Western Lakes \& Rivers Region of Table 3. Travel Expenditures in Kentucky by Regions, 2001 \& 2002 at Kentucky.gov. "2002 Economic Impact Figures (word document)," COMMERCE CABINET News, http://tourism.ky.gov/news.asp (accessed May 22, 2006). And Table A. Alphabetical by county of 2001 Impact of Travel on Tennessee at TENNESSEE.GOV. "TIA Economic Impact Reports for 2001," Research \& Reports, Department of Tourist Development (accessed May 22, 2006)).
} 
of sales in the region and 5-6 percent of jobs. In 2000, hotel sales in the area were $\$ 90$ million, supporting 2,272 jobs in the hotels and lodging sector (Minnesota IMPLAN Group 2000).

Table 2. Economic activity in the Lake Barkley region, 2000.

\begin{tabular}{|c|c|c|c|c|c|}
\hline \multirow[b]{2}{*}{ Industry } & \multirow[b]{2}{*}{$\begin{array}{c}\text { Output } \\
\text { (\$ millions) }\end{array}$} & \multirow[b]{2}{*}{ Employment } & \multicolumn{3}{|c|}{ Employee } \\
\hline & & & $\begin{array}{l}\text { Compensation } \\
\text { (\$ millions) }\end{array}$ & $\begin{array}{l}\text { Value Added } \\
\text { (\$ millions) }\end{array}$ & $\%$ Output \\
\hline Agriculture, forestry, fish & 528.54 & $15,146.14$ & 30.18 & 208.89 & $2 \%$ \\
\hline Mining & 142.18 & 854.86 & 31.11 & 71.79 & $1 \%$ \\
\hline Construction & $2,112.11$ & $20,687.60$ & 461.25 & 731.74 & $8 \%$ \\
\hline Food processing & $1,040.98$ & $5,514.99$ & 161.48 & 227.57 & $4 \%$ \\
\hline Apparel & 192.67 & $1,797.01$ & 46.59 & 57.53 & $1 \%$ \\
\hline Manufacturing & $6,005.80$ & $29,230.07$ & $1,314.21$ & $2,027.90$ & $23 \%$ \\
\hline Sporting goods & 41.85 & 294.74 & 10.97 & 19.95 & $0 \%$ \\
\hline Auto parts and access & 733.37 & $3,427.51$ & 164.91 & 222.22 & $2.8 \%$ \\
\hline Transp. and commu. & $1,367.21$ & $9,498.23$ & 312.59 & 561.38 & $5 \%$ \\
\hline Other services & $3,010.59$ & $56,022.33$ & $1,243.05$ & $1,785.44$ & $12 \%$ \\
\hline Wholesale trade & 752.07 & $8,621.71$ & 294.26 & 514.91 & $3 \%$ \\
\hline Retail & $1,330.57$ & $33,800.71$ & 576.01 & $1,060.53$ & $5 \%$ \\
\hline Eating and drinking & 460.16 & $14,141.76$ & 149.37 & 228.67 & $2 \%$ \\
\hline $\begin{array}{l}\text { Finance, insurance and real } \\
\text { estate }\end{array}$ & $2,407.94$ & $11,368.34$ & 240.26 & $1,715.83$ & $9 \%$ \\
\hline Hotels and lodging places & 90.00 & $2,271.76$ & 27.22 & 50.87 & $0.3 \%$ \\
\hline Auto services & 212.57 & $3,059.47$ & 49.84 & 123.84 & $1 \%$ \\
\hline Other amusements & 66.39 & $1,486.08$ & 14.28 & 26.99 & $0.3 \%$ \\
\hline Amusement and rec services & 30.38 & $1,354.53$ & 8.12 & 18.58 & $0.1 \%$ \\
\hline Gov't and other & $5,263.37$ & $66,006.72$ & $2,788.19$ & $4,151.81$ & $20 \%$ \\
\hline Total & $25,793.97$ & $284,586.57$ & $7,924.00$ & $13,806.93$ & $100 \%$ \\
\hline
\end{tabular}




\section{Private Dock Owner Survey, 1998-99}

The Ecological Resources Branch (ERB) of the US Army Engineer Research and Development Center (ERDC) surveyed private dock owners at Lake Sidney Lanier (Georgia), Lake Barkley (Kentucky/Tennessee), and Hartwell Lake (Georgia/North Carolina/South Carolina). The ERB staff designed the survey, constructed the instrument, and provided the frame (a list of private dock owners) to the Institution for Public Policy and Social Research (IPPSR) at Michigan State University (MSU) for sampling. IPPSR obtained additional approval through MSU's Human Subjects Office. The Office of Management and Budget authorized this study (Institute for Water Resources (IWR) 2006).

Working with the project managers, the ERB obtained lists of private dock owners. Once the contact information was received, MSU IPPSR staff sent a pre-contact mailer to the dock owners in the sample. This information packet included a description of the study and a FAQ sheet for the dock owner. In addition, the dock owners received a worksheet outlining the spending categories and other information regarding the upcoming telephone interview. Calls were made to dock owners in the randomly ordered sequence, until a quota of interviews was completed. In this manner, 328 randomly selected private dock owners were interviewed at Lake Barkley, representing 38 percent of the total of 853 eligible private docks ${ }^{1}$ at the time of the survey.

Spending and trip information were obtained through a Computer Assisted Telephone Interview (CATI) survey conducted by MSU IPPSR staff. Dock owners were asked to document the number of boating trips on the lake that originated from their dock and to report trip spending associated with their most recent trip. Spending information was collected only for the most recent trip to reduce recall bias and avoid selective recall in which owners may report spending on the most expensive trips. The telephone interview lasted an average of 15 minutes. Other information needed to estimate parameters for this population was also acquired during the interview.

\footnotetext{
${ }_{1}^{1}$ Number of private docks derived from 1998 NRMS data.
} 


\section{Results}

Results are provided in four parts: respondent profiles (including socioeconomic characteristics); recreation trip characteristics (amount of boat use, recreation activities, and boat type); per-trip and annual spending; and the economic impacts of dock owners'/users' spending on the local region surrounding Lake Barkley.

\section{Respondent profiles}

The general characteristics of private dock owners as individuals and by households at Lake Barkley are shown in Figures 2 to 11. In general, the private dock owners were mostly white males with high education and income. Among the respondents, 79 percent were male and 92 percent were aged 46 and above (Figures 2 and 3 ). The average age was 61 (range $=31$ to 90 years old). The most frequent age (mode) was 62. Fifty-nine percent of the dock owners had at least some college education and 40 percent had college degrees or more. Thirteen percent of Barkley's private dock owners held graduate degrees (Figure 4). Almost all of the owners interviewed were white (Figure 5). All private dock slips have registered boats; surveys may or may not have been conducted with the registered boat owner.

Ninety-six percent of the owners were also the registered boat owner at the time of the interview (Figure 6).

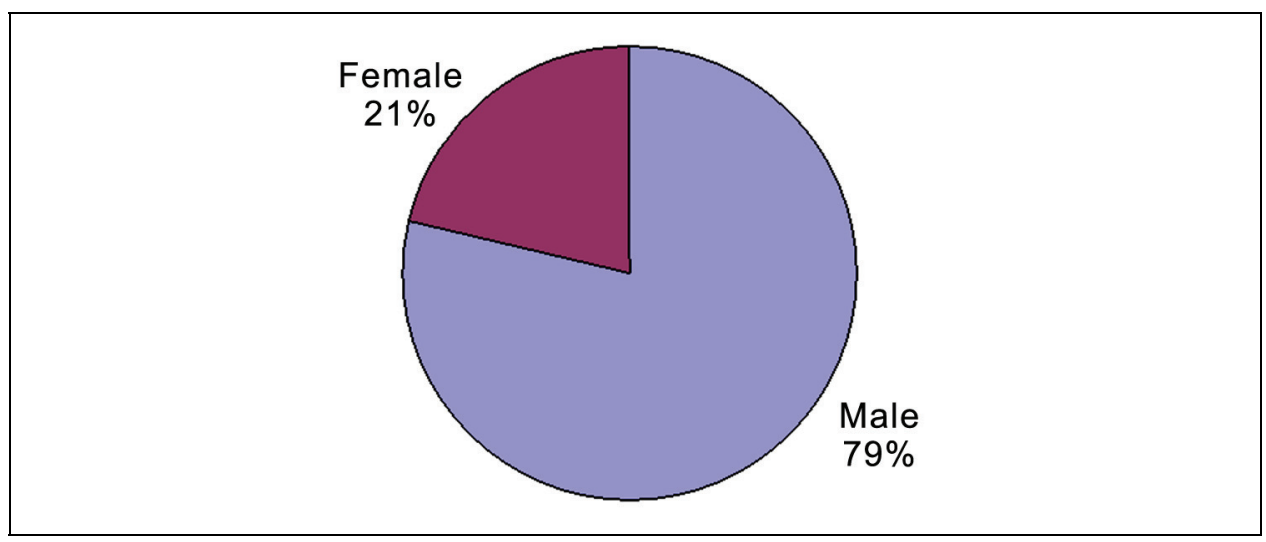

Figure 2. Gender of private dock owners at Lake Barkley, 1999 ( $N=327)$. 


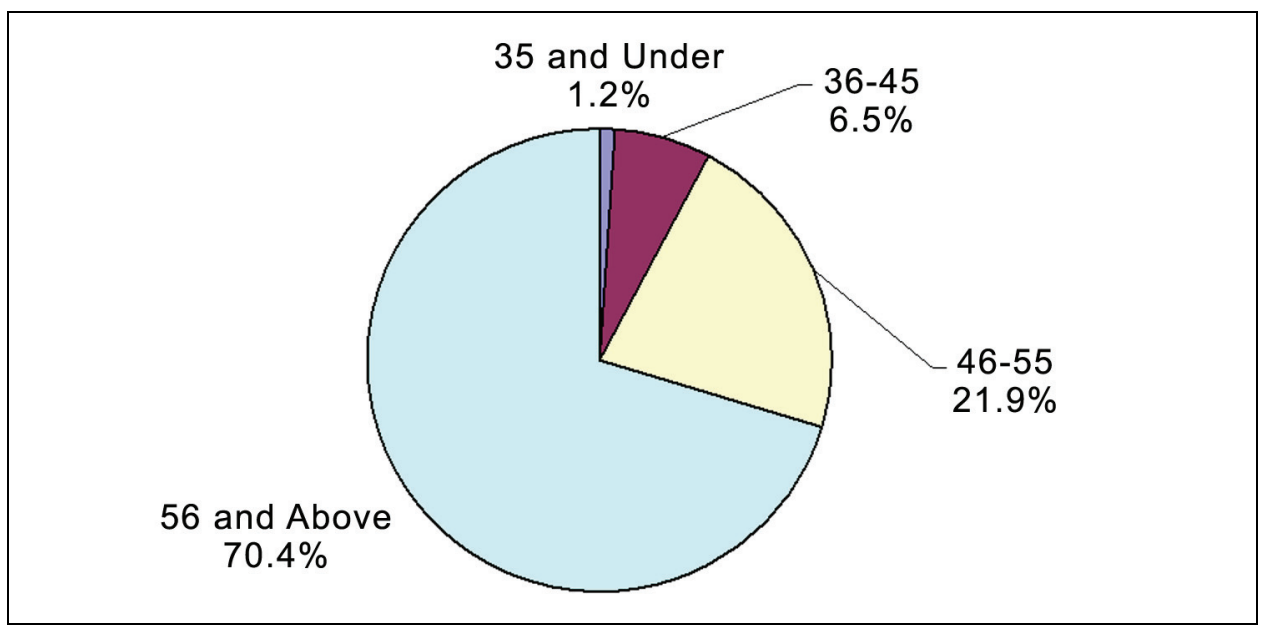

Figure 3. Age of private dock owners at Lake Barkley, 1999 ( $\mathrm{N}=324)$.

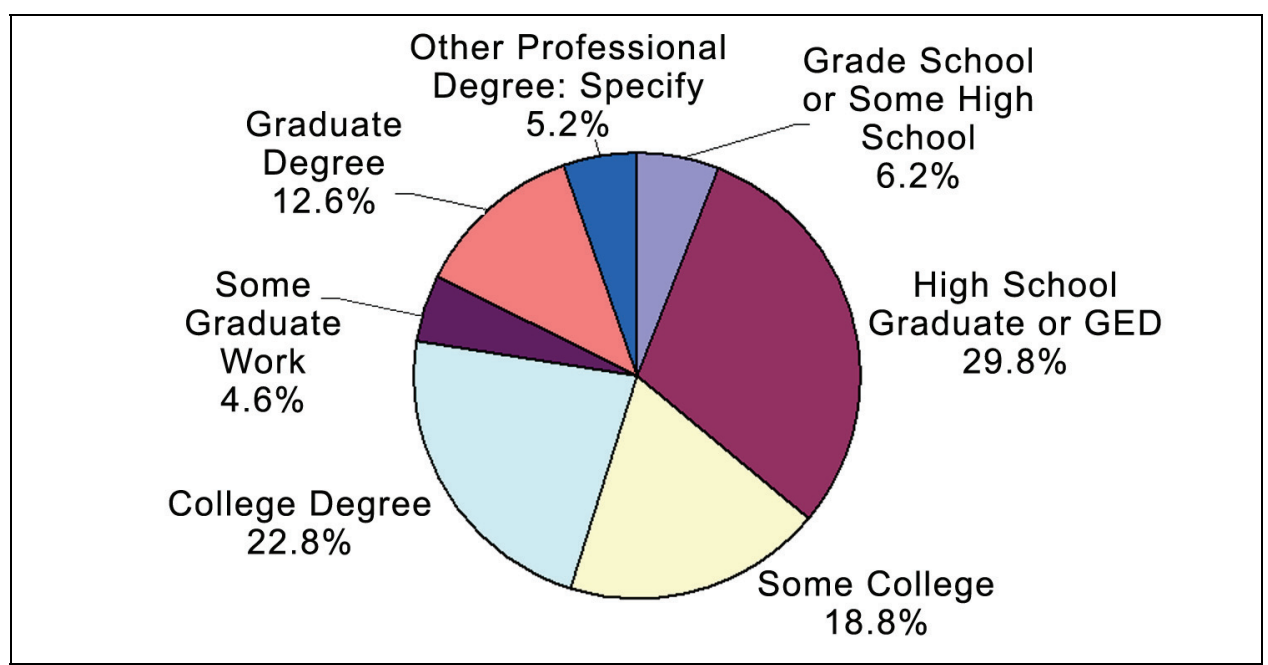

Figure 4. Education of private dock owners at Lake Barkley, 1999 ( $N=325)$.

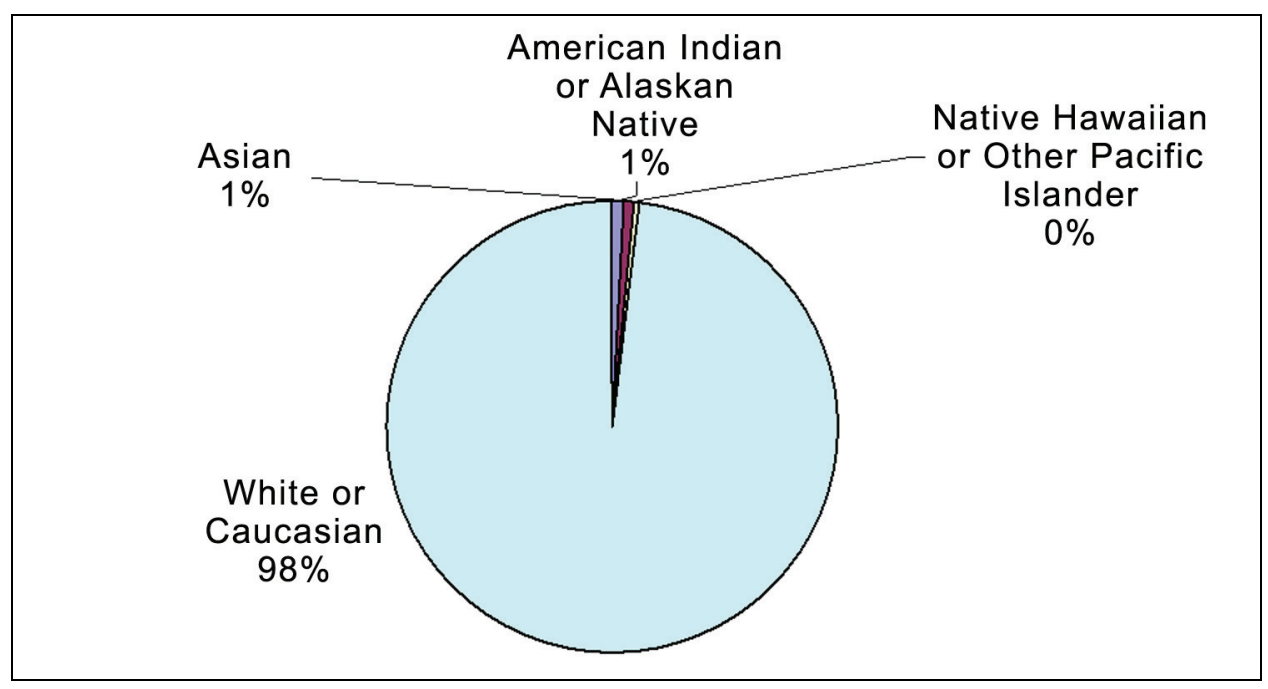

Figure 5. Race of private dock owners at Lake Barkley, $1999(\mathrm{~N}=325)$ (about 1 percent were Hispanic or of Latino origin). 


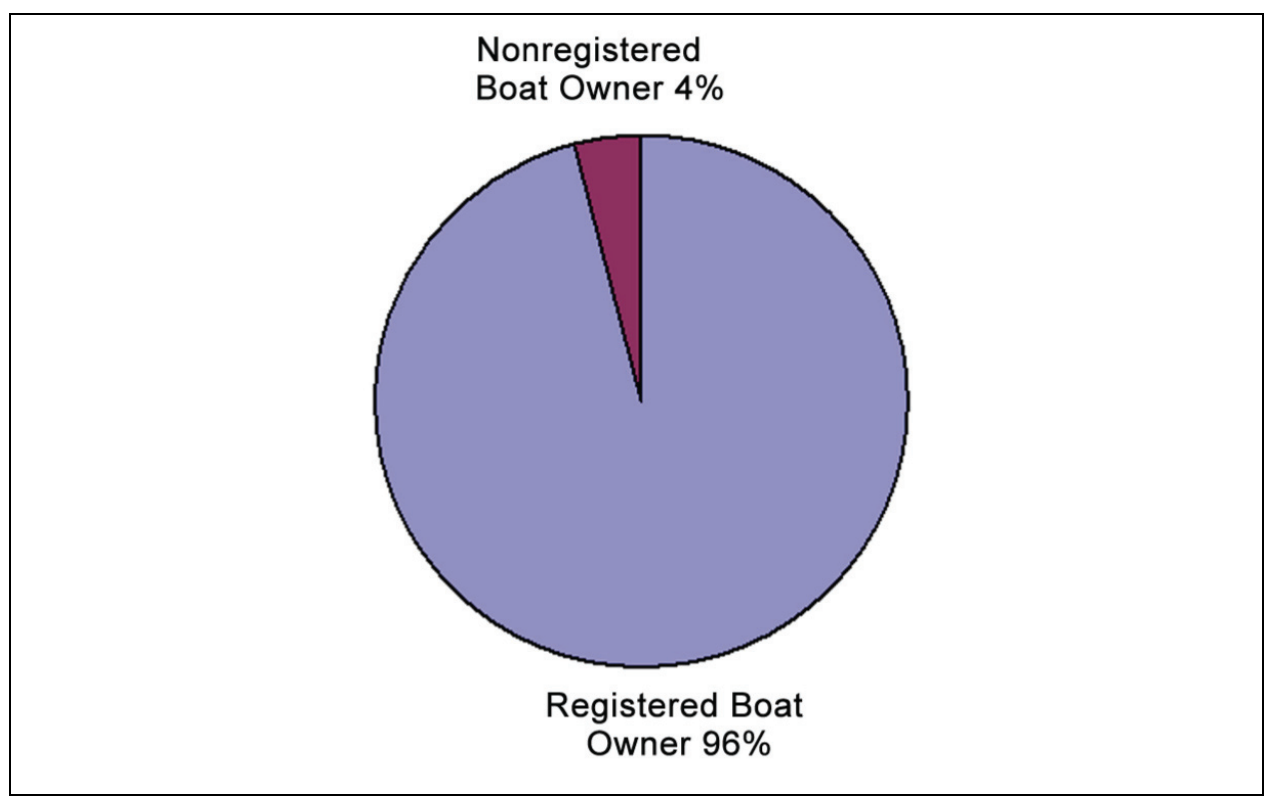

Figure 6. Survey conducted with registered boat owners at Lake Barkley private docks, $1999(\mathrm{~N}=328)$.

Many private dock owners reported high household incomes with no or few children living in the household. Forty percent of the respondents had annual household incomes of at least $\$ 80,000$, with 30 percent reporting incomes of over $\$ 100,000$ (Figure 7). More than two thirds of the owners lived in a household with two or less people and 81 percent of the owners did not have any children age under 18 in their households (Figures 8 and 9). The average number of individuals per household was 3 . The most frequent household size (mode) was 2.

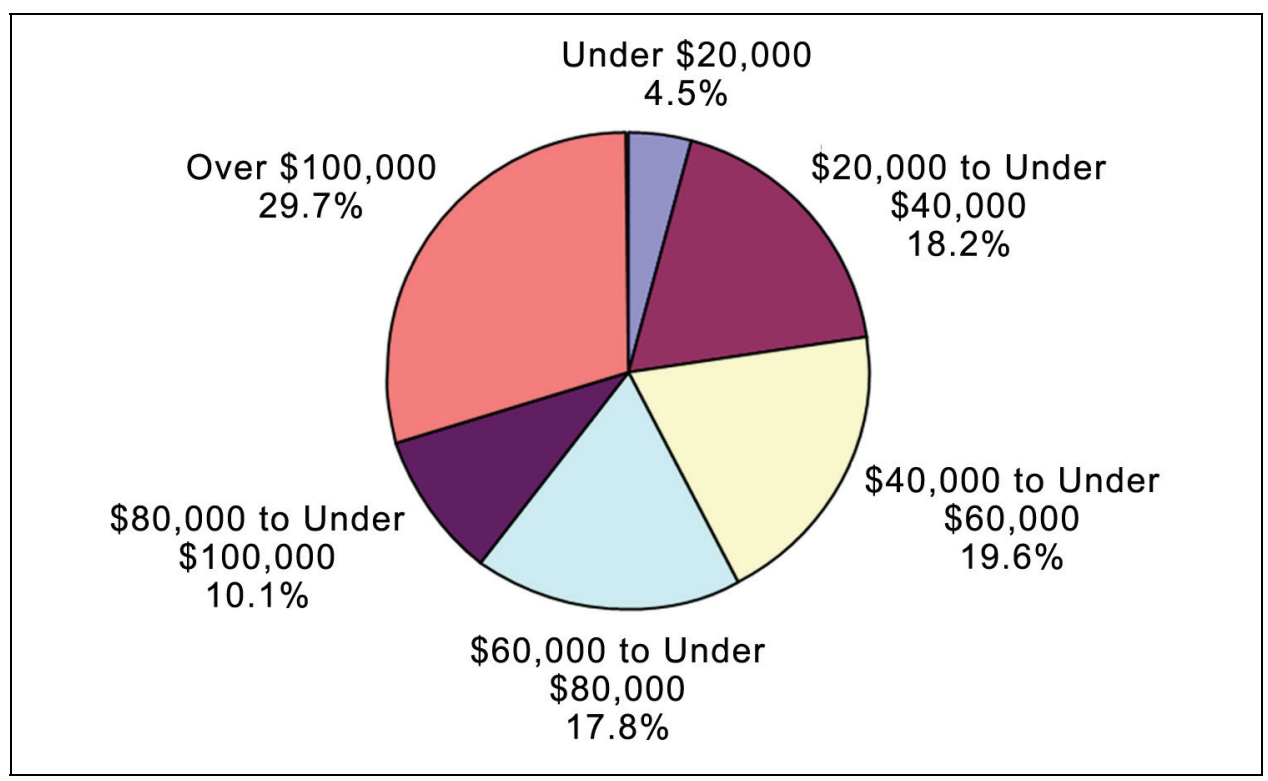

Figure 7. Household income of private dock owners at Lake Barkley, 1999 (N=286). 


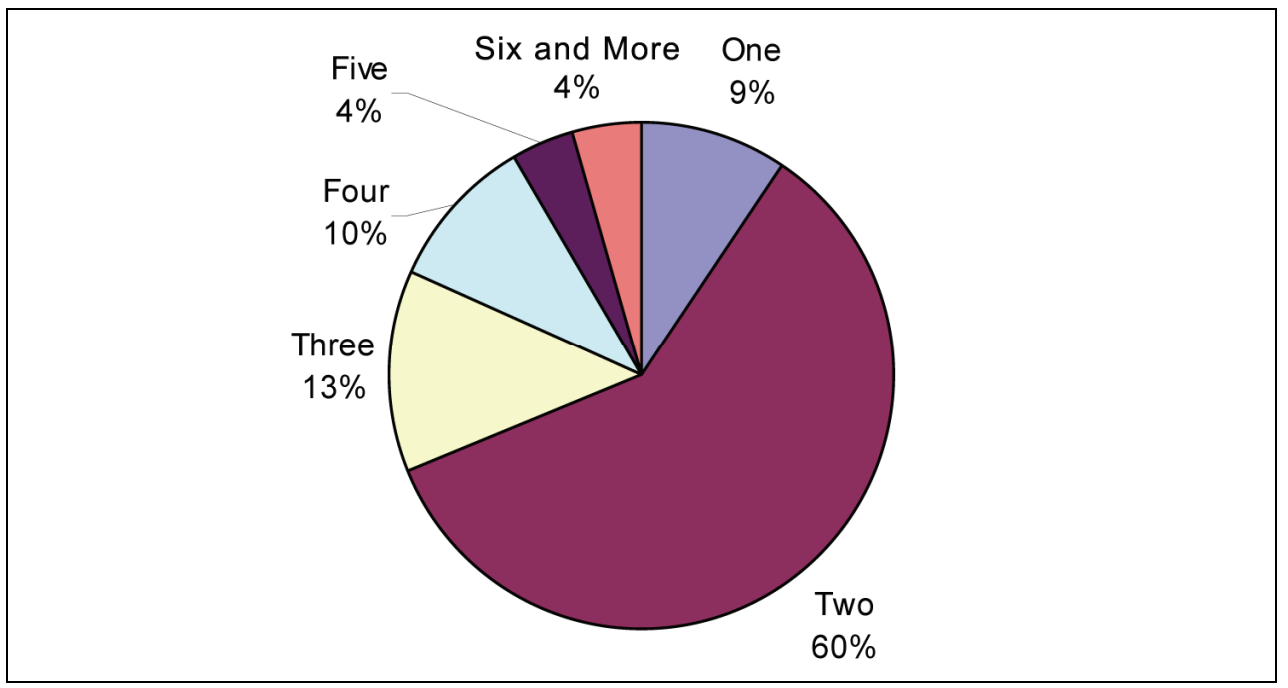

Figure 8. Household size of private dock owners at Lake Barkley, $1999(\mathrm{~N}=320)$.

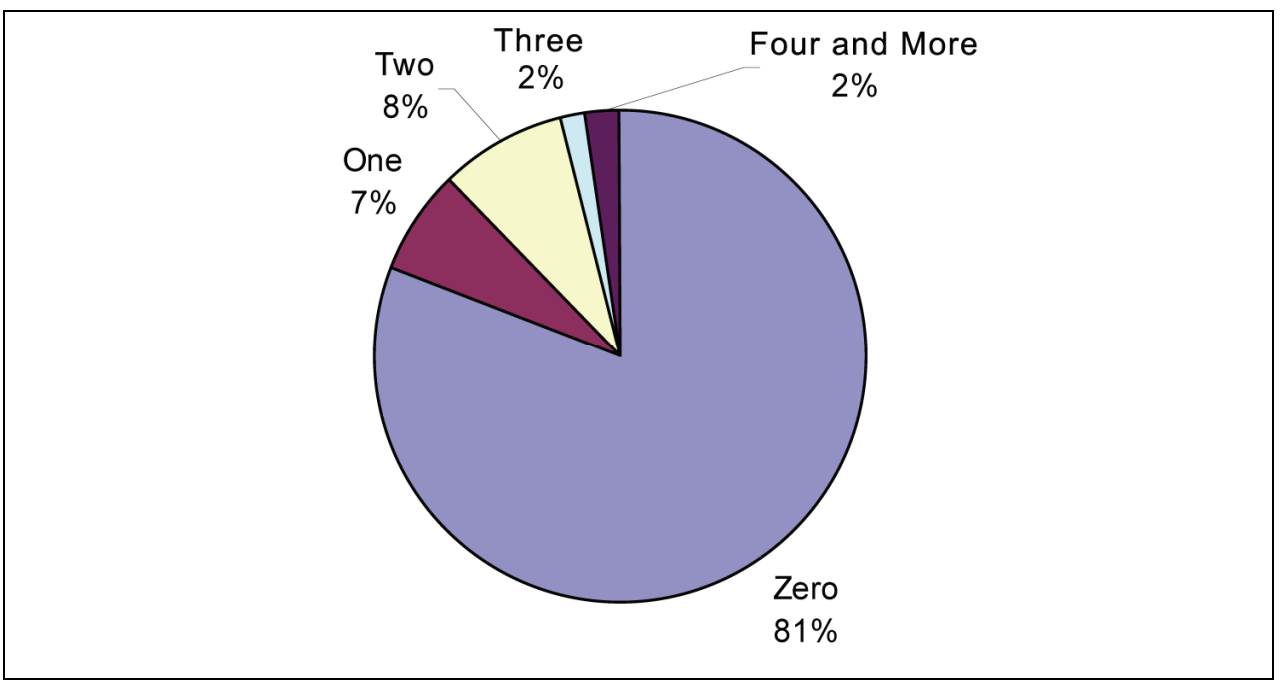

Figure 9. Number of people under 18 in households of private dock owners at Lake Barkley, $1999(\mathrm{~N}=324)$.

The permanent residences of 62 percent of the owners were within 30 miles of the dock (Figure 10). The average distance from the dock owner's permanent home to the dock was 57 miles. Forty-seven percent of the dock owners owned a seasonal home within 30 miles of the dock (Figure 11). 


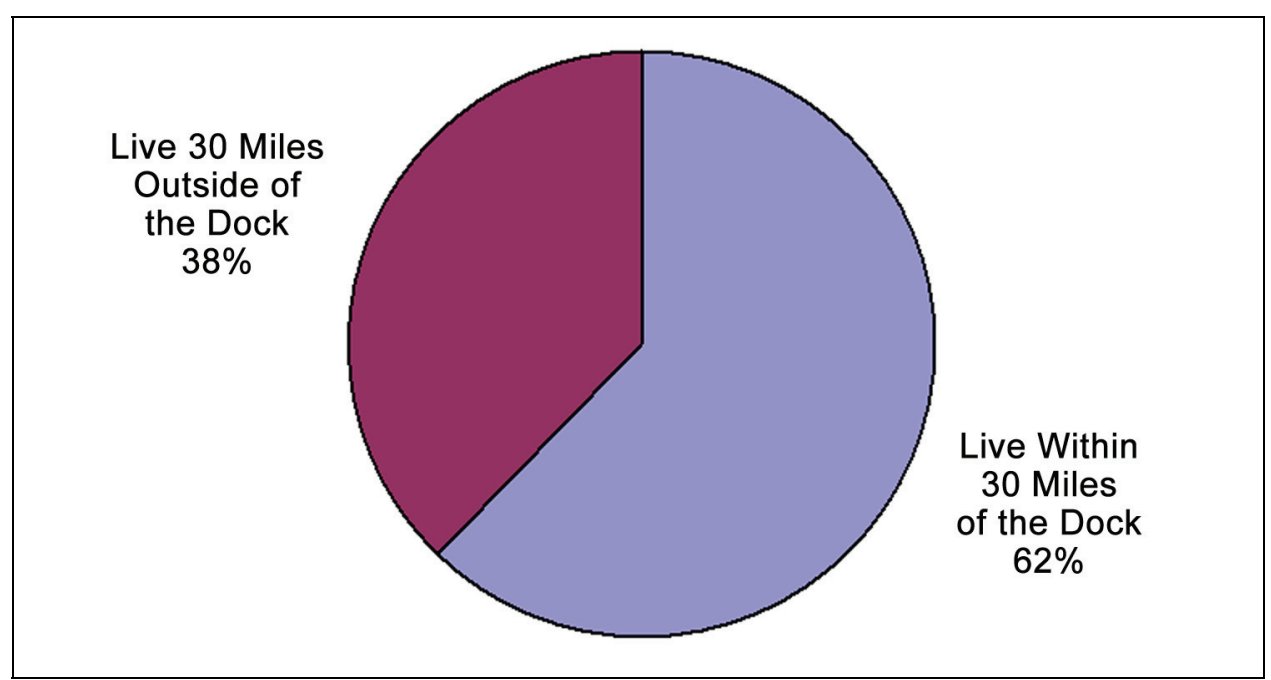

Figure 10. Permanent residence of private dock owners at Lake Barkley, 1999 (N=328).

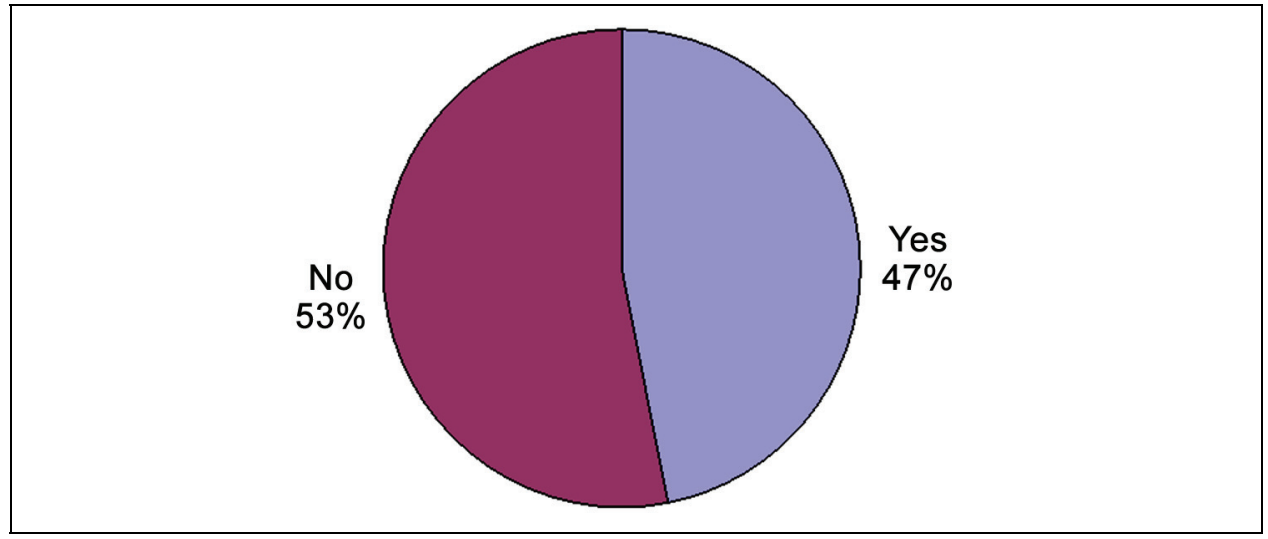

Figure 11. Seasonal home ownership of private dock owners at Lake Barkley, $1999(\mathrm{~N}=328)$.

\section{Boating characteristics}

Respondents had been boating on Lake Barkley for an average of 16 years (range $=53$ years). On average, they and their guests took 53.8 boating trips the previous year from September 1, 1998 to August 31, 1999. ${ }^{1}$ Half of them made 25 or fewer trips and 25 percent made 50 or more trips in the same period (Table 3). The majority of trips were taken in the summer (21.3 trips), followed by spring ( 15 trips). On average, the fewest number of trips were made in the winter (about five trips per dock owner). When asked to compare the number of boating trips made last year to the previous three years, 66 percent of the owners felt that they had made about the same number of boating trips. Nine percent said they had taken more

\footnotetext{
1 Sixty-two percent of the sampled dock owners had permanent residences within 30 miles of their private boat dock. Therefore, a large proportion of trips are local in origin.
} 
trips last year than in the previous three years, and 25 percent said they had taken fewer trips (Figure 12).

Table 3. Trips to Lake Barkley private boat docks the previous year (09/01/1998 to 08/31/1999).

\begin{tabular}{|c|c|c|c|c|c|c|c|c|}
\hline & \multirow[b]{2}{*}{ Average } & \multirow[b]{2}{*}{ Std. Error } & \multirow[b]{2}{*}{ Minimum } & \multirow[b]{2}{*}{ Maximum } & \multicolumn{3}{|c|}{ Percentiles } & \multirow[b]{2}{*}{$\mathrm{N}$} \\
\hline & & & & & $25 \%$ & $50 \%$ & $75 \%$ & \\
\hline Total number of trips & 53.76 & 4.15 & 0 & 365 & 15 & 25 & 50 & 297 \\
\hline Trips made in fall & 10.98 & 0.99 & 0 & 100 & 2 & 5 & 10 & 290 \\
\hline Trips made in winter & 5.18 & 0.76 & 0 & 100 & 0 & 1 & 5 & 291 \\
\hline Trips made in spring & 15.17 & 1.38 & 0 & 140 & 3 & 6 & 15 & 290 \\
\hline Trips made in summer & 21.25 & 1.83 & 0 & 180 & 4 & 10 & 20 & 290 \\
\hline
\end{tabular}

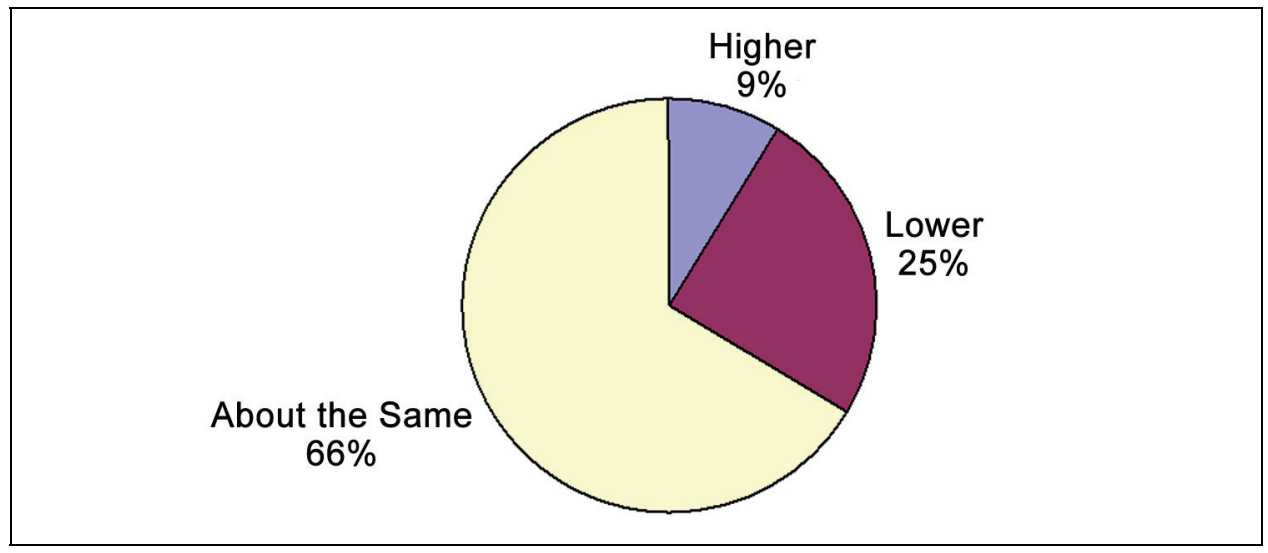

Figure 12. Number of boating trips made by private dock owners last year compared to previous 3-year average at Lake Barkley, $1999(\mathrm{~N}=294)$.

\section{Activities while boating}

During their boating trips the previous year, dock owners/users went fishing from boats during 40 percent of their trips for an average of 21 times across the year (Table 4). Other activities they participated in during their boating trips including swimming (on 32 percent of their boating trips), fishing from the shore (18 percent), picnicking (17 percent), and water skiing (16 percent). The participation rates for camping, scuba diving, and hunting were all less than 1 percent of the total boating trips. Thirty-eight percent of the dock owners/users reported participating in other activities that were not mentioned during the telephone interviews (Figure 13). On average, dock owners/users participated in other activities 12 times during 23 percent of their boating trips the previous year (Table 4). The most 
frequent other activities were sightseeing (9 percent of respondents) and tubing/wave running (8 percent of respondents) (Figure 13).

Table 4. Recreation activity participation during previous year's trips to Lake Barkley private boat docks (09/01/1998 to 08/31/1999).

\begin{tabular}{|l|r|l|l|l|r|l||}
\hline \hline Activity & Mean & $\begin{array}{l}\text { Percent of } \\
\text { Total Trips }\end{array}$ & $\begin{array}{l}\text { Std. Error } \\
\text { of Mean }\end{array}$ & Minimum & Maximum & N \\
\hline \hline Boating & 36.64 & $68.15 \%$ & 3.73 & 0 & 365 & 265 \\
\hline Swimming & 17.26 & $32.11 \%$ & 1.71 & 0 & 225 & 266 \\
\hline Picnicking & 9.14 & $17.01 \%$ & 1.80 & 0 & 300 & 270 \\
\hline Fishing from boat & 21.41 & $39.83 \%$ & 2.51 & 0 & 300 & 270 \\
\hline Water skiing & 8.41 & $15.64 \%$ & 1.06 & 0 & 160 & 270 \\
\hline Camping & 0.25 & $0.46 \%$ & 0.11 & 0 & 20 & 270 \\
\hline Hiking & 2.83 & $5.26 \%$ & 1.35 & 0 & 360 & 271 \\
\hline Fishing from shore & 9.67 & $17.99 \%$ & 1.77 & 0 & 300 & 264 \\
\hline Scuba diving & 0.07 & $0.13 \%$ & 0.04 & 0 & 8 & 272 \\
\hline Hunting & 0.35 & $0.65 \%$ & 0.23 & 0 & 60 & 271 \\
\hline Other activities & 12.21 & $22.70 \%$ & 2.40 & 0 & 300 & 266 \\
\hline $\begin{array}{l}\text { 1 Times participated in listed activity during previous year's boating trip. } \\
\text { 2 Times participated in the listed activity divided by total number of boating trips made the previous year. }\end{array}$ \\
\hline
\end{tabular}

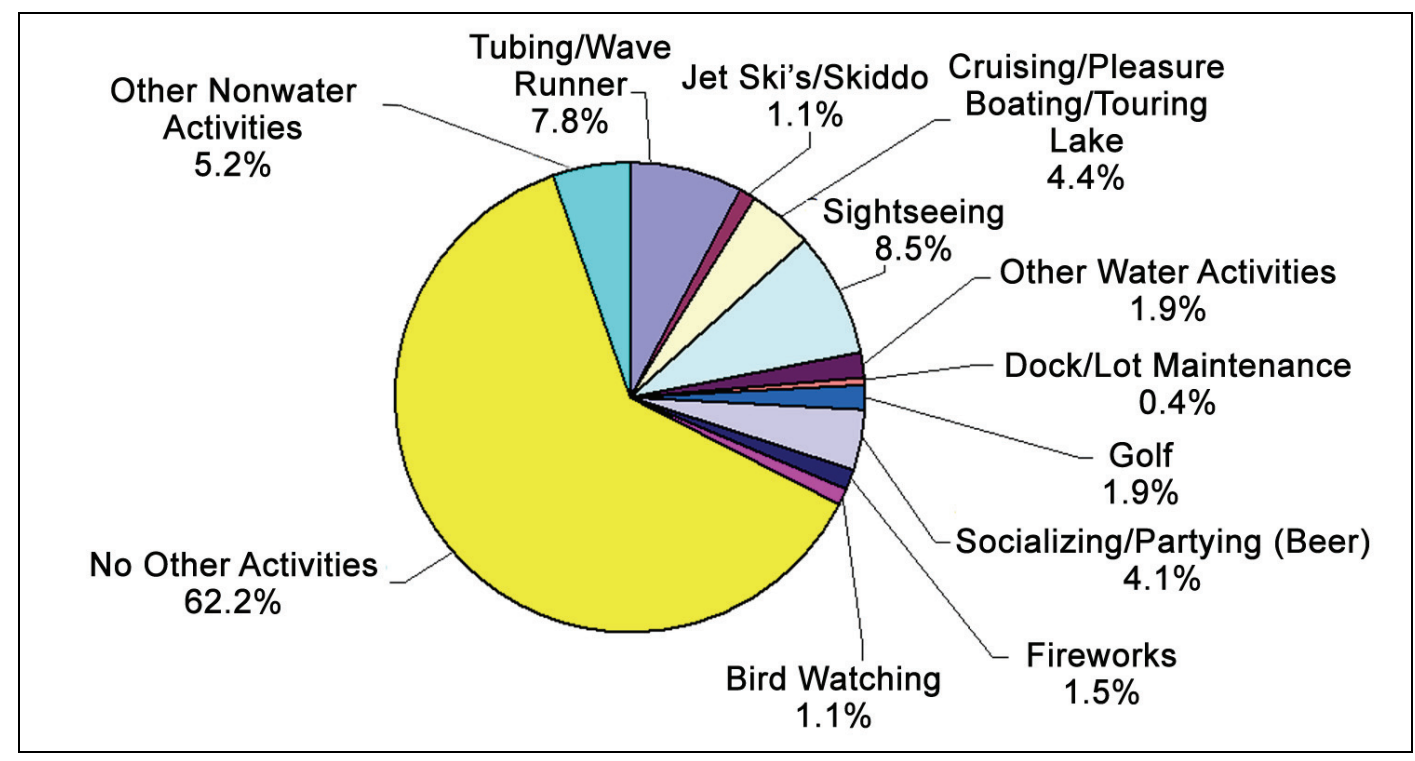

Figure 13. "What other activities did you or others participate in during your boating trips last year that I have not already mentioned?" (from Lake Barkley Private Docks, 1999, N=270). 


\section{Type of boat and motor}

Thirty-two percent of the boats surveyed at Lake Barkley private docks were $17 \mathrm{ft}$ and under with a minimum of $5 \mathrm{ft}$ (Table 5). Forty-two percent were 18 to $23 \mathrm{ft}$ long, and 27 percent were $24 \mathrm{ft}$ and larger with a maximum of $44 \mathrm{ft}$. Sailboats, pontoons, and houseboats were mostly $24 \mathrm{ft}$ and larger.

Table 5. Boat type and length cross-tabulation, Lake Barkley private dock owner survey, $1999(\mathrm{~N}=278)$.

\begin{tabular}{|c|c|c|c|c|c|c|c|}
\hline \multirow[b]{2}{*}{ Boat Length } & \multicolumn{6}{|c|}{ Boat Type } & \multirow[b]{2}{*}{ Total } \\
\hline & Open & Cabin & Sailboat & Pontoon & Houseboat & Other & \\
\hline $17^{\prime}$ and smaller & $25.54 \%$ & $0.00 \%$ & $0.00 \%$ & $1.44 \%$ & $0.00 \%$ & $4.68 \%$ & $31.65 \%$ \\
\hline $18^{\prime}$ to $23^{\prime}$ & $26.98 \%$ & $1.08 \%$ & $0.00 \%$ & $13.67 \%$ & $0.00 \%$ & $0.00 \%$ & $41.73 \%$ \\
\hline 24' and larger & $2.16 \%$ & $1.08 \%$ & $0.72 \%$ & $22.30 \%$ & $0.36 \%$ & $0.00 \%$ & $26.62 \%$ \\
\hline Total & $54.68 \%$ & $2.16 \%$ & $0.72 \%$ & $37.41 \%$ & $0.36 \%$ & $4.68 \%$ & $100.00 \%$ \\
\hline
\end{tabular}

Seventy-two percent of the boats used at private docks did not include inboard motors. The majority of cabin cruisers and houseboats had inboard motors, while most pontoons and open did not (Table 6). In general, the median boats (18 to $23 \mathrm{ft}$ long) had the largest percentage of outboard motors (Table 7).

Table 6. Boat type and motor cross-tabulation, Lake Barkley private dock owner survey, $1999(\mathrm{~N}=257)$.

\begin{tabular}{|c|c|c|c|c|c|c|c|}
\hline \multirow[b]{2}{*}{ Inboard Motor } & \multicolumn{6}{|c|}{ Boat Type } & \multirow[b]{2}{*}{ Total } \\
\hline & Open & Cabin & Sailboat & Pontoon & Houseboat & Other & \\
\hline With & $15.95 \%$ & $1.56 \%$ & $0.39 \%$ & $7.00 \%$ & $0.39 \%$ & $3.11 \%$ & $28.40 \%$ \\
\hline Without & $36.19 \%$ & $0.39 \%$ & $0.39 \%$ & $31.52 \%$ & $0.00 \%$ & $3.11 \%$ & $71.60 \%$ \\
\hline Total & $52.14 \%$ & $1.95 \%$ & $0.78 \%$ & $38.52 \%$ & $0.39 \%$ & $6.23 \%$ & $100.00 \%$ \\
\hline
\end{tabular}

Table 7. Boat length and motor cross-tabulation, Lake Barkley private dock owner survey, $1999(\mathrm{~N}=250)$.

\begin{tabular}{|l|c|c|c|c|}
\hline \multirow{2}{*}{ Inboard Motor } & \multicolumn{3}{|c|}{ Boat Length } & \multirow{2}{*}{ Total } \\
\cline { 2 - 4 } & $\mathbf{2 0}$ ' and Smaller & 21' to 30' & 31' and Larger & $28.80 \%$ \\
\hline \hline With & $8.40 \%$ & $12.00 \%$ & $8.40 \%$ & $71.20 \%$ \\
\hline Without & $22.80 \%$ & $30.40 \%$ & $18.00 \%$ & $100.00 \%$ \\
\hline Total & $31.20 \%$ & $42.40 \%$ & $26.40 \%$ & . \\
\hline
\end{tabular}




\section{Dock user segments and spending}

Spending averages were estimated for all Lake Barkley's private dock users (Table 8) and for two different segments based on length of stay (Table 9) and boat length (Table 10). Dividing visitors into segments helps explain differences in spending across distinct user groups. It gives managers the opportunity to apply these distinct spending profiles to project level use data. The two types of segments that fulfilled these purposes were: day user versus overnight stay segments and segments based on length of the boat.

\section{Average spending for full sample of dock owners}

Private dock users averaged $\$ 194$ in trip expenses associated with their last boating trip (for a party of 4.2 people). Dock users stayed away from home an average of 1.4 nights and used their boat 1.9 days during their last trip (Table 8). Seventy-three percent (\$142) of spending occurred within 30 miles of their boat dock. Of the expenditures made within 30 miles of their dock, dock users spent the most on restaurant meals (\$33 per party trip), followed by groceries ( $\$ 27$ ), gas and oil for their boat ( $\$ 26)$, and other supplies ( $\$ 14)$. A refined average of 53.8 boating trips were made from each slip in a private dock during the previous year.

A private dock is permitted under a shoreline use permit. The applicant is charged a $\$ 30$ fee for a 5-year permit, which includes a $\$ 10$ administration charge and a $\$ 5$ annual inspection fee. Other storage fees that are identified in annual spending do not include the permit fee but relate to additional spending that may be paid by the end user; for example, in off-site storage when the craft is not in the water.

Dock owners spent an average of $\$ 83$ on storage fees, $\$ 226$ on insurance, $\$ 265$ on boat repair and maintenance, and $\$ 337$ on dock repair and maintenance (Table 8). The average cost of the boat was $\$ 13,754$ (1999 dollars). The lowest boat cost was $\$ 109$ and the highest was $\$ 76,598$. 
Table 8. Summary of Lake Barkley private dock owners'/users' spending and use profiles, 09/1998 to 08/1999 (spending per party trip).

\begin{tabular}{|c|c|c|c|c|c|c|c|c|}
\hline Spending Categories & Mean & $\begin{array}{l}\text { Std. } \\
\text { Error }\end{array}$ & $\begin{array}{l}\text { Pct. } \\
\text { Error }^{1}\end{array}$ & $\mathrm{~N}$ & $\begin{array}{l}\text { Mini- } \\
\text { mum }\end{array}$ & $\begin{array}{l}\text { Maxi- } \\
\text { mum }\end{array}$ & $\begin{array}{c}\text { Pct. } \\
\text { Zeroes }\end{array}$ & $\begin{array}{c}\text { Mean } \\
\text { Exc. Zero }\end{array}$ \\
\hline \multicolumn{9}{|c|}{ Spending Information for Last Trip } \\
\hline Gas/oil auto & $\$ 11.38$ & $\$ 1.75$ & $15 \%$ & 323 & $\$ 0$ & $\$ 400$ & $64 \%$ & $\$ 31.41$ \\
\hline Other expenses auto & $\$ 3.63$ & $\$ 1.80$ & $50 \%$ & 322 & $\$ 0$ & $\$ 500$ & $95 \%$ & $\$ 78.00$ \\
\hline Gas/oil boat & $\$ 26.32$ & $\$ 2.27$ & $9 \%$ & 314 & $\$ 0$ & $\$ 400$ & $15 \%$ & $\$ 31.07$ \\
\hline Other expenses boat & $\$ 11.29$ & $\$ 3.56$ & $32 \%$ & 320 & $\$ 0$ & $\$ 800$ & $91 \%$ & $\$ 120.43$ \\
\hline $\begin{array}{l}\text { Food/drink restau- } \\
\text { rants }\end{array}$ & $\$ 33.08$ & $\$ 3.24$ & $10 \%$ & 322 & $\$ 0$ & $\$ 400$ & $47 \%$ & $\$ 61.94$ \\
\hline Groceries & $\$ 26.92$ & $\$ 2.74$ & $10 \%$ & 320 & $\$ 0$ & $\$ 300$ & $50 \%$ & $\$ 54.18$ \\
\hline Campground fees & $\$ 0.46$ & $\$ 0.24$ & $52 \%$ & 323 & $\$ 0$ & $\$ 60$ & $98 \%$ & $\$ 30.00$ \\
\hline Lodging & $\$ 0.58$ & $\$ 0.32$ & $56 \%$ & 324 & $\$ 0$ & $\$ 80$ & $98 \%$ & $\$ 37.80$ \\
\hline Recreation fees & $\$ 8.75$ & $\$ 1.76$ & $20 \%$ & 322 & $\$ 0$ & $\$ 250$ & $89 \%$ & $\$ 76.14$ \\
\hline Sporting goods & $\$ 5.29$ & $\$ 1.30$ & $25 \%$ & 323 & $\$ 0$ & $\$ 268$ & $87 \%$ & $\$ 41.71$ \\
\hline Other supplies & $\$ 14.42$ & $\$ 2.83$ & $20 \%$ & 321 & $\$ 0$ & $\$ 600$ & $64 \%$ & $\$ 40.26$ \\
\hline Total within 30 miles & $\$ 142.14$ & & & & & & & \\
\hline $\begin{array}{l}\text { Expenses for 30+ } \\
\text { miles }^{2}\end{array}$ & $\$ 51.86$ & $\$ 7.25$ & $14 \%$ & 166 & $\$ 0.00$ & $\$ 600.00$ & $48 \%$ & \\
\hline Total trip spending ${ }^{2}$ & $\$ 194.00$ & & & & & & & \\
\hline $\begin{array}{l}\text { Pct. of local spend- } \\
\text { ing (within } 30 \text { miles) }\end{array}$ & $73.27 \%$ & & & & & & & \\
\hline \multicolumn{9}{|c|}{ Use Information for Last Trip } \\
\hline $\begin{array}{l}\text { Nights away from } \\
\text { home }\end{array}$ & 1.44 & 0.15 & $10 \%$ & 321 & 0 & 16 & & \\
\hline Days used boat & 1.87 & 0.10 & $6 \%$ & 275 & 1 & 11 & & \\
\hline $\begin{array}{l}\text { Number of people on } \\
\text { boat }\end{array}$ & 4.23 & 0.19 & $4 \%$ & 279 & 1 & 27 & & \\
\hline \multicolumn{9}{|c|}{ Annual Spending for Last Year (09/01/98 - 08/31/99) } \\
\hline Storage fees & $\$ 82.85$ & $\$ 10.61$ & $13 \%$ & 257 & $\$ 0$ & $\$ 750$ & & \\
\hline Insurance payments & $\$ 226.41$ & $\$ 16.20$ & $7 \%$ & 210 & $\$ 0$ & $\$ 2,000$ & & \\
\hline $\begin{array}{l}\text { Boat repair/ } \\
\text { maintenance }\end{array}$ & $\$ 265.21$ & $\$ 34.67$ & $13 \%$ & 257 & $\$ 0$ & $\$ 5,000$ & & \\
\hline $\begin{array}{l}\text { Dock maintenance/ } \\
\text { repair }\end{array}$ & $\$ 336.94$ & $\$ 56.07$ & $17 \%$ & 281 & $\$ 0$ & $\$ 7,000$ & & \\
\hline \multicolumn{9}{|c|}{ Use Information for Last Year (09/01/98 - 08/31/99) } \\
\hline $\begin{array}{l}\text { Number of trips } \\
\text { using boat }\end{array}$ & 53.78 & 4.16 & $8 \%$ & 296 & 0 & 365 & & \\
\hline $\begin{array}{l}\text { Cost of the boat } \\
\text { (in } 1999 \text { dollars) }\end{array}$ & $\$ 13,754$ & $\$ 627$ & $5 \%$ & 236 & $\$ 109$ & $\$ 76,598$ & & \\
\hline
\end{tabular}


When asked to compare the amount spent on their most recent trip to prior similar trips, 79 percent of the dock owners felt that they had made about the same expenditures. Ten percent said they had spent more on the most recent trip than on similar trips in the past 12 months, and 11 percent said they had spent less (Figure 14).

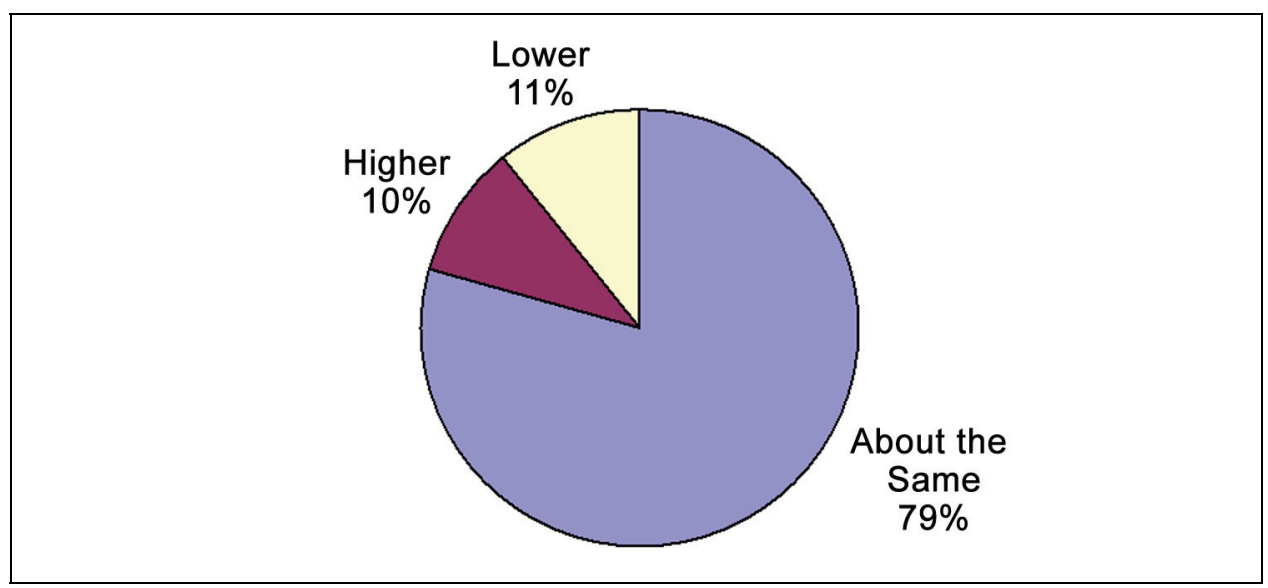

Figure 14. Expenditures by private dock owners/users on most recent trip compared to similar trips in the last 12 months at Lake Barkley, $1999(\mathrm{~N}=307)$.

Many of the respondents reported no spending on their last trip in many of the spending categories listed. Categories in which a large percentage (more than 80 percent) of users did not spend money on their last trip were: campground fees (98 percent), lodging (98 percent), other expenses on auto ( 95 percent), other expenses on boat ( 91 percent), recreation fees (89 percent), and sporting goods (87 percent). Although the estimates of average trip expenditures in this report are based on the full sample, it is worthwhile to recognize the difference between the average spending of all private dock users and average spending of just the spenders. The average spending of those who spent something on an item is generally much higher than the average computed from all visitors. For instance, while the average across all dock users was $\$ 0.58$ on lodging per party trip, the five dock parties who did spend money on lodging spent an average of $\$ 38$ per party trip (Table 8). For estimating total spending of all Lake Barkley private dock users, it is appropriate to apply the means that include zeros. The means without zeros should not be used to expand the data to population totals, as they represent spending for specific segments only (i.e., dock users who stayed in hotels spent an average of $\$ 38$ on lodging per trip). 


\section{Average spending by segment: Day use vs. overnight}

Barkley dock owners were grouped into two segments based on whether or not they stayed overnight away from their permanent home during their last trip. The dock owners/users who did not stay away from home (i.e., day users) spent an average of $\$ 92$ for that trip, 78 percent (\$72) of which was spent within 30 miles of the boat dock (Table 9). The average party size was 4.0 people per trip. The dock owners/users who stayed overnight spent an average of 3.8 nights away from home and used the boat for 3.1 days with a party size of 4.6 people per trip. They spent an average $\$ 333$ for the entire trip, 78 percent (\$261) of which was spent within 30 miles of the dock. Day users made an average of 66 boating trips in the previous year, whereas overnight dock users made 36 trips.

Dock owners in the overnight segment owned more expensive boats than day users ( $\$ 15,175$ vs. $\$ 12,936$, respectively). Consequently, they paid more annually in insurance payments, storage fees, and repairs and maintenance than day users.

Day users comprised 62 percent of the sample of dock users, while 38 percent spent at least one night in the area on their last trip. In terms of total spending in the local region, day users of private docks contributed 46 percent and overnight stay dock users, 54 percent.

\section{Average spending by boat length segments}

Based on the length of the boat, the dock owners were grouped into three segments: boats that were $17 \mathrm{ft}$ and shorter, boats between 18 and $23 \mathrm{ft}$, and boats $24 \mathrm{ft}$ and longer. An increase in boat size did not necessarily mean the amount of expenditures increased as well. The $17-\mathrm{ft}$ and smaller segment spent an average of $\$ 154$ per party on the last trip during which about 80 percent ( $\$ 123$ ) was spent within 30 miles of the dock (Table 10). They stayed an average of 1.7 nights away from home and used their boat for 2 days with a party size of 3.2 people per trip. Dock users in this segment made an average of 63 boating trips the previous year. 
Table 9. Spending and use by length of stay segments, Lake Barkley private dock owner survey, 09/1998 to 08/1999 (spending per party trip).

\begin{tabular}{|c|c|c|c|c|c|c|c|c|}
\hline \multirow[b]{2}{*}{ Spending Categories } & \multicolumn{4}{|c|}{ Day Users } & \multicolumn{4}{|c|}{ Overnight Users } \\
\hline & Mean & $\begin{array}{l}\text { Std. } \\
\text { Error }\end{array}$ & $\begin{array}{l}\text { Pct. } \\
\text { Error }^{1}\end{array}$ & $\mathrm{~N}$ & Mean & $\begin{array}{l}\text { Std. } \\
\text { Error }\end{array}$ & $\begin{array}{l}\text { Pct. } \\
\text { Error }^{1}\end{array}$ & $\mathrm{~N}$ \\
\hline \multicolumn{9}{|c|}{ Per Party Trip Spending } \\
\hline Gas/oil auto & \$1.82 & $\$ 0.49$ & $27 \%$ & 199 & \$27.58 & $\$ 4.31$ & $16 \%$ & 119 \\
\hline Other expenses auto & $\$ 1.01$ & $\$ 1.01$ & $100 \%$ & 198 & $\$ 8.15$ & $\$ 4.55$ & $56 \%$ & 119 \\
\hline Gas/oil boat & $\$ 15.70$ & $\$ 1.20$ & $8 \%$ & 193 & $\$ 43.88$ & $\$ 5.40$ & $12 \%$ & 117 \\
\hline Other expenses boat & $\$ 8.71$ & $\$ 4.47$ & $51 \%$ & 197 & $\$ 15.94$ & $\$ 6.10$ & $38 \%$ & 119 \\
\hline Restaurants & $\$ 16.26$ & $\$ 2.45$ & $15 \%$ & 198 & $\$ 61.11$ & $\$ 6.99$ & $11 \%$ & 120 \\
\hline Groceries & $\$ 10.30$ & $\$ 2.06$ & $20 \%$ & 198 & $\$ 55.64$ & $\$ 5.71$ & $10 \%$ & 118 \\
\hline Campground fees & $\$ 0.00$ & - & - & 199 & $\$ 1.25$ & $\$ 0.64$ & $51 \%$ & 120 \\
\hline Lodging & $\$ 0.00$ & - & - & 199 & $\$ 1.56$ & $\$ 0.86$ & $55 \%$ & 121 \\
\hline Recreation fees & $\$ 5.25$ & $\$ 2.05$ & $39 \%$ & 198 & $\$ 14.81$ & $\$ 3.23$ & $22 \%$ & 120 \\
\hline Sporting goods & $\$ 2.50$ & $\$ 0.74$ & $30 \%$ & 198 & $\$ 10.04$ & $\$ 3.21$ & $32 \%$ & 121 \\
\hline Other supplies & $\$ 10.38$ & $\$ 3.09$ & $30 \%$ & 197 & $\$ 21.13$ & $\$ 5.56$ & $26 \%$ & 120 \\
\hline Total within 30 miles & $\$ 71.95$ & & & & $\$ 261.08$ & & & \\
\hline Expenses $30+$ miles $^{2}$ & $\$ 20.54$ & $\$ 7.27$ & $35 \%$ & 65 & $\$ 72.17$ & $\$ 10.71$ & $15 \%$ & 98 \\
\hline Total trip spending & $\$ 92.49$ & & & & $\$ 333.26$ & & & \\
\hline $\begin{array}{l}\text { Pct. of local spending (within } \\
30 \text { miles) }\end{array}$ & $78 \%$ & & & & $78 \%$ & & & \\
\hline \multicolumn{9}{|c|}{ Annual Spending } \\
\hline Storage fees & \$71.57 & \$13.31 & $19 \%$ & 155 & $\$ 103.03$ & \$17.88 & $17 \%$ & 99 \\
\hline Insurance payments & $\$ 205.08$ & $\$ 17.98$ & $9 \%$ & 128 & $\$ 263.70$ & $\$ 30.93$ & $12 \%$ & 80 \\
\hline Boat repair/maintenance & $\$ 226.63$ & $\$ 38.40$ & $17 \%$ & 155 & $\$ 333.66$ & $\$ 66.58$ & $20 \%$ & 99 \\
\hline Dock maintenance/repair & $\$ 334.53$ & $\$ 70.74$ & $21 \%$ & 174 & $\$ 349.73$ & $\$ 94.89$ & $27 \%$ & 104 \\
\hline $\begin{array}{l}\text { Cost of the boat (in } 1999 \\
\text { dollars) }\end{array}$ & $\$ 12,936$ & $\$ 802$ & $6 \%$ & 141 & $\$ 15,175$ & $\$ 1,006$ & $7 \%$ & 93 \\
\hline \multicolumn{9}{|c|}{ Visitor Characteristics } \\
\hline $\begin{array}{l}\text { Total trips using boat (last } \\
\text { year) }\end{array}$ & 66.20 & 5.89 & $9 \%$ & 177 & 36.01 & 5.27 & $15 \%$ & 115 \\
\hline $\begin{array}{l}\text { Nights away from home (last } \\
\text { trip) }\end{array}$ & 0.00 & - & - & 200 & 3.83 & 0.27 & $7 \%$ & 121 \\
\hline Days used boat (last trip) & 1.00 & - & - & 165 & 3.09 & 0.20 & $6 \%$ & 107 \\
\hline People on boat (last trip) & 4.00 & 0.19 & $5 \%$ & 167 & 4.59 & 0.39 & $9 \%$ & 107 \\
\hline
\end{tabular}


The 18- to 23- $\mathrm{ft}$ boat segment spent an average of $\$ 238$ per party on the last trip ( $\$ 167$ within 30 miles of the dock). They stayed an average of 1.6 nights away from home, used their boat for 1.9 days with a party size of 4.4 people per trip. They made an average of 53 boating trips the previous year. Owners/users in the largest boat size segment averaged more than $\$ 166$ per party on goods and services during their last trip ( $\$ 116$ of the money was spent locally). They stayed away from home an average of 1 night and used the boat for 1.5 days per trip. The average party size for this group was 5.2 people per trip. Owners/users in this segment made an average of 61 boating trips the previous year.

In general, the larger the boat, the more dock owners spent on annual expenses. Storage fees ranged from $\$ 71$ for boats $17 \mathrm{ft}$ and shorter to $\$ 111$ for boats $24 \mathrm{ft}$ and longer. The cost of the boat ranged from $\$ 9,221$ for the 17 - $\mathrm{ft}$ and smaller segment to $\$ 15,262$ for the $24-\mathrm{ft}$ and larger segment, while the insurance payments ranged from $\$ 161$ to $\$ 312$ a year across the three segments. Boat repair and maintenance costs similarly grew from $\$ 198$ to $\$ 358$ per year as boat size increased (Table 10).

One-third of the sample had small-sized boats (17 ft and smaller), while 42 percent were medium (18 to $23 \mathrm{ft}$ ) and 27 percent were large (above $23 \mathrm{ft}$ ). Dock users with large boats contributed 23 percent of total spending locally, dock users with medium-sized boats, 46 percent, and those with small boats, 31 percent.

\section{Total spending}

The figures in Table 11 were derived from secondary data sources, the Natural Resource Management System (NRMS) (USACE 2006c), and from survey data for Lake Barkley (e.g., average number of trips per household or dock permit last year). Applying these figures, Barkley dock users took 51,237 boating party trips in 1999 (3.7 percent of total recreation use ${ }^{1}$ ), and purchased 61 new boats (Table 11).

\footnotetext{
14.1 million recreation visits in 1999 from Table 1 divided by an average party size of 3.0 from Propst et al. (1998) equals 1.37 total million party trips; 51,237 is 3.7 percent of 1.37 million party trips.
} 
Table 10. Spending and use by boat length segments, Lake Barkley private dock owner survey, 09/1998 to 08/1999, (spending per party trip).

\begin{tabular}{|c|c|c|c|c|c|c|c|c|c|c|c|c|}
\hline \multirow[b]{2}{*}{ Spending Categories } & \multicolumn{4}{|c|}{20 and Smaller } & \multicolumn{4}{|c|}{$21^{\prime}$ to $30^{\prime}$} & \multicolumn{4}{|c|}{ 31' and Larger } \\
\hline & Mean & $\begin{array}{l}\text { Std. } \\
\text { Error }\end{array}$ & $\begin{array}{l}\text { Pct. } \\
\text { Error }^{1}\end{array}$ & $\mathrm{~N}$ & Mean & $\begin{array}{l}\text { Std. } \\
\text { Error }\end{array}$ & $\begin{array}{l}\text { Pct. } \\
\text { Error }{ }^{1}\end{array}$ & $\mathrm{~N}$ & Mean & $\begin{array}{l}\text { Std. } \\
\text { Error }\end{array}$ & $\begin{array}{l}\text { Pct. } \\
\text { Error }^{1}\end{array}$ & $\mathrm{~N}$ \\
\hline \multicolumn{13}{|c|}{ Per Party Trip Spending } \\
\hline Gas/oil auto & $\$ 10.64$ & $\$ 1.78$ & $17 \%$ & 88 & $\$ 14.81$ & $\$ 3.98$ & $27 \%$ & 113 & $\$ 7.15$ & $\$ 1.88$ & $26 \%$ & 73 \\
\hline Other expenses auto & $\$ 3.26$ & $\$ 2.40$ & $74 \%$ & 86 & $\$ 0.69$ & $\$ 0.39$ & $56 \%$ & 116 & $\$ 1.55$ & $\$ 0.87$ & $0 \%$ & 71 \\
\hline Gas/oil boat & $\$ 21.86$ & $\$ 2.70$ & $12 \%$ & 85 & $\$ 29.17$ & $\$ 3.28$ & $11 \%$ & 112 & $\$ 29.38$ & $\$ 4.37$ & $15 \%$ & 72 \\
\hline Other expenses boat & $\$ 10.19$ & $\$ 5.92$ & $58 \%$ & 85 & $\$ 20.93$ & $\$ 8.77$ & $42 \%$ & 115 & $\$ 3.29$ & $\$ 1.39$ & $0 \%$ & 73 \\
\hline Restaurants & $\$ 26.77$ & $\$ 4.54$ & $17 \%$ & 87 & $\$ 40.92$ & $\$ 5.80$ & $14 \%$ & 114 & $\$ 32.74$ & $\$ 6.71$ & $21 \%$ & 73 \\
\hline Groceries & $\$ 26.59$ & $\$ 4.87$ & $18 \%$ & 86 & $\$ 29.64$ & $\$ 5.37$ & $18 \%$ & 115 & $\$ 21.84$ & $\$ 3.78$ & $17 \%$ & 73 \\
\hline Campground fees & $\$ 0.68$ & $\$ 0.48$ & $70 \%$ & 88 & $\$ 0.74$ & $\$ 0.56$ & $76 \%$ & 115 & $\$ 0.07$ & $\$ 0.07$ & $0 \%$ & 73 \\
\hline Lodging & $\$ 0.45$ & $\$ 0.45$ & $100 \%$ & 88 & $\$ 0.53$ & $\$ 0.48$ & $91 \%$ & 115 & $\$ 0.00$ & $\$ 0.00$ & $0 \%$ & 73 \\
\hline Recreation fees & $\$ 5.45$ & $\$ 1.77$ & $33 \%$ & 88 & $\$ 12.82$ & $\$ 3.64$ & $28 \%$ & 114 & $\$ 4.38$ & $\$ 2.38$ & $0 \%$ & 72 \\
\hline Sporting goods & $\$ 4.48$ & $\$ 1.80$ & $40 \%$ & 87 & $\$ 5.59$ & $\$ 2.57$ & $46 \%$ & 115 & $\$ 5.16$ & $\$ 1.76$ & $34 \%$ & 73 \\
\hline Other supplies & $\$ 12.42$ & $\$ 4.06$ & $33 \%$ & 86 & $\$ 10.75$ & $\$ 2.39$ & $22 \%$ & 114 & $\$ 10.30$ & $\$ 2.33$ & $23 \%$ & 73 \\
\hline Total within $\mathbf{3 0}$ miles & $\$ 122.79$ & & & & $\$ 166.60$ & & & & $\$ 115.85$ & & & \\
\hline Expenses $30+$ miles$^{2}$ & $\$ 30.79$ & $\$ 7.87$ & $26 \%$ & 48 & $\$ 71.69$ & $\$ 15.50$ & $22 \%$ & 62 & $\$ 49.65$ & $\$ 12.07$ & $24 \%$ & 43 \\
\hline Total trip spending & $\$ 153.59$ & & & & $\$ 238.29$ & & & & $\$ 165.50$ & & & \\
\hline Pct. of local spending (within 30 miles) & $80 \%$ & & & & $70 \%$ & & & & $70 \%$ & & & \\
\hline \multicolumn{13}{|c|}{ Annual Spending } \\
\hline Storage fees & $\$ 71.45$ & $\$ 19.00$ & $27 \%$ & 76 & $\$ 72.55$ & $\$ 15.03$ & $21 \%$ & 105 & $\$ 110.69$ & $\$ 23.96$ & $22 \%$ & 65 \\
\hline Insurance payments & $\$ 161.40$ & $\$ 17.11$ & $11 \%$ & 60 & $\$ 225.03$ & $\$ 16.25$ & $7 \%$ & 91 & $\$ 311.62$ & $\$ 53.54$ & $17 \%$ & 52 \\
\hline Boat repair/maintenance & $\$ 198.36$ & $\$ 49.09$ & $25 \%$ & 76 & $\$ 249.97$ & $\$ 49.37$ & $20 \%$ & 106 & $\$ 357.97$ & $\$ 89.58$ & $25 \%$ & 64 \\
\hline Dock maintenance/repair & $\$ 430.47$ & $\$ 131.24$ & $30 \%$ & 75 & $\$ 300.70$ & $\$ 84.28$ & $28 \%$ & 105 & $\$ 358.29$ & $\$ 126.53$ & $35 \%$ & 65 \\
\hline Cost of the boat (in 1999 dollars) & $\$ 9,220.68$ & $\$ 1,215.89$ & $13 \%$ & 68 & $\$ 16,147.66$ & $\$ 841.11$ & $5 \%$ & 98 & $\$ 15,261.62$ & $\$ 1,220.85$ & $8 \%$ & 64 \\
\hline
\end{tabular}




\begin{tabular}{|c|c|c|c|c|c|c|c|c|c|c|c|c|}
\hline \multicolumn{13}{|c|}{ Visitor Characteristics } \\
\hline Total trips using boat (last year) & 62.61 & 9.15 & $15 \%$ & 79 & 52.50 & 6.32 & $12 \%$ & 106 & 60.73 & 9.02 & $15 \%$ & 66 \\
\hline Nights away from home (last trip) & 1.67 & 0.32 & $19 \%$ & 85 & 1.61 & 0.24 & $15 \%$ & 116 & 0.96 & 0.18 & $18 \%$ & 73 \\
\hline Days used boat (last trip) & 1.98 & 0.22 & $11 \%$ & 84 & 1.91 & 0.16 & $8 \%$ & 115 & 1.47 & 0.10 & $7 \%$ & 70 \\
\hline People on boat (last trip) & 3.21 & 0.20 & $6 \%$ & 86 & 4.36 & 0.30 & $7 \%$ & 115 & 5.21 & 0.48 & $9 \%$ & 71 \\
\hline
\end{tabular}


Table 11. Total annual use figures for private dock owner survey at Lake Barkley (1999).

\begin{tabular}{|l|c|l||}
\hline Category & Total Use & Computation Procedures \\
\hline \hline Number of docks & 953 & From NRMS (1999) \\
\hline Number of boats & 1,045 & From NRMS (1999) \\
\hline Number of party trips & 51,237 & $\begin{array}{l}\text { Total party trips (from Table 3) times total number } \\
\text { of docks (assuming the total number of trips is on } \\
\text { a per dock basis, reference Foreword) }\end{array}$ \\
\hline $\begin{array}{l}\text { Percent of new boats purchased } \\
\text { last year }\end{array}$ & $6.36 \%$ & $\begin{array}{l}\text { Computed from survey results, using the 3-year } \\
\text { average (1997 to 1999) }\end{array}$ \\
\hline $\begin{array}{l}\text { Number of new boats purchased } \\
\text { last year }\end{array}$ & 61 & $\begin{array}{l}\text { Percent of new boats purchased last year times } \\
\text { total number of docks }\end{array}$ \\
\hline
\end{tabular}

Local and total trip-related spending (Tables 12 and 13) is calculated by multiplying the number of party-trips in Table $11(51,237)$ by the trip spending averages in Table 8 . Total spending on boats and fixed, annual goods and services (Table 14) is estimated by multiplying the number of docks in Table 11 (953) by the annual expenditures on boats, dock repairs and maintenance, and storage in Table 8 . Total spending on insurance is estimated by multiplying the number of boats $(1,045)$ by the proportion of local boat dock owners who purchased boat insurance and their average insurance payment. Total spending on purchasing new boats is estimated by multiplying the number of new boats purchased last year (61) by the proportion of local dock owners who bought new boats and the average local new boat cost for three years: 1997-1999.

Table 12. Total trip spending in local area ${ }^{1}$ by Lake Barkley private dock owners/users (1999).

\begin{tabular}{|l|l|}
\hline Spending Category & Spending (\$MM) \\
\hline \hline Gas/oil auto & $\$ 0.58$ \\
\hline Other expenses auto & $\$ 0.19$ \\
\hline Gas/oil boat & $\$ 1.35$ \\
\hline Other expenses boat & $\$ 0.58$ \\
\hline Food/drink restaurants & $\$ 1.70$ \\
\hline Groceries & $\$ 1.38$ \\
\hline Campground fees & $\$ 0.02$ \\
\hline Lodging & $\$ 0.03$ \\
\hline Recreation fees & $\$ 0.45$ \\
\hline Sporting goods & $\$ 0.27$ \\
\hline Other supplies & $\$ 0.74$ \\
\hline Total trip spending & $\$ 7.28$ \\
\hline \hline 1 Local trip spending equals spending within 30 miles of the private dock. & \\
\hline
\end{tabular}


Table 13. Total trip spending ${ }^{1}$ by Lake Barkley private dock owners/users (1999).

\begin{tabular}{|l|l||}
\hline Spending Category & Spending (\$MM) ${ }^{2}$ \\
\hline \hline Gas/oil auto & $\$ 0.87$ \\
\hline Other expenses auto & $\$ 0.28$ \\
\hline Gas/oil boat & $\$ 1.35$ \\
\hline Other expenses boat & $\$ 0.58$ \\
\hline Food/drink restaurants & $\$ 2.54$ \\
\hline Groceries & $\$ 2.06$ \\
\hline Campground fees & $\$ 0.04$ \\
\hline Lodging & $\$ 0.04$ \\
\hline Recreation fees & $\$ 0.67$ \\
\hline Sporting goods & $\$ 0.41$ \\
\hline Other supplies & $\$ 1.11$ \\
\hline Total trip spending & $\$ 9.94$ \\
\hline \hline $\begin{array}{l}1 \text { Total trip spending equals spending within and outside 30 miles of the dock. } \\
2 \text { Dock owners were asked to report trip spending outside 30 miles of the private dock as one total amount, } \\
\text { not broken down by item as this table shows. This aggregate spending figure was then proportionally dis- } \\
\text { tributed into all but two categories based on the spending proportions within 30 miles. Proportional alloca- } \\
\text { tions were not made to the "gas/oil boat" and "other expenses boat" categories. It was assumed that, for } \\
\text { these two categories, there were no boating expenditures outside 30 miles of the private dock. }\end{array}$ \\
\hline
\end{tabular}

Table 14. Total spending on fixed, annual goods and services by private dock owners at Lake Barkley (1999).

\begin{tabular}{|l|l||}
\hline Spending Category & Spending (\$MM) \\
\hline \hline Storage fees & $\$ 0.08$ \\
\hline $\begin{array}{l}\text { Insurance payments (include only payments from dock owners } \\
\text { who lived within 30 miles of the private dock) }\end{array}$ & $\$ 0.14$ \\
\hline Boat repair/maintenance & $\$ 0.25$ \\
\hline Dock maintenance/repair & $\$ 0.32$ \\
\hline Purchases of new boats (within 30 miles) & $\$ 0.54$ \\
\hline Total durable goods spending & $\$ 1.33$ \\
\hline
\end{tabular}

A recreation visit, as reported in the NRMS database, is one person entering a Corps project. Spending depends on how long a person stays in the local region rather than how many times they enter the project or how much time they spend in recreation activities while there. Recreation 
visits are therefore converted to party trips ${ }^{1}$ in the region before applying spending averages. This procedure avoids double-counting the spending of private dock users who may enter the project multiple times on the same day and also takes into account additional days a dock user may spend in the area outside the project.

The estimated trip spending for all Barkley private dock users in 1999 was $\$ 7.28$ million spent within the local region (Table 12). If trip spending outside 30 miles is included, the total rises to $\$ 9.94$ million (Table 13). Only trip spending within 30 miles of the private boat dock ( $\$ 7.28$ million) should be included when conducting economic impact analysis at the project level (multi-county region).

Fixed, annual goods and services related to boating activities in this study were new boats, storage fees, insurance, and repairs and maintenance. Barkley's private dock owners spent $\$ 1.3$ million (1999 dollars) on boating-related annual goods and services (Table 14). Forty-one percent of the money was spent on purchases of new boats $(\$ 540,000)$, followed by dock maintenance and repair $(\$ 320,000)$, boat repair and maintenance $(\$ 250,000)$, insurance payments $(\$ 140,000)$, and storage fees $(\$ 80,000)$.

\section{Economic impacts of dock user spending}

\section{9 impacts}

The \$7.28 million in trip-related spending from Table 12 had a direct economic impact on the region of $\$ 4.4$ million in direct sales, $\$ 1.6$ million in personal income (wages and salaries), and supported 105 jobs in the region (Table 15). The eating and drinking (restaurants and bars) sector received the largest amount of direct sales ( $\$ 1.7$ million), followed by the retail sector (\$1 million).

Direct effects are less than total spending, as only the retail and wholesale margins on visitor purchases of goods accrue to the local economy. The local region surrounding Lake Barkley captures 60 percent of dock user

\footnotetext{
1 See Table 11 for the conversion steps. A party is a travel group staying in the area (within 30 miles of the dock). The travel group is usually all individuals in the same vehicle or on the same boat or staying in the same room or campsite. During the interviews, dock owners were asked to report expenditures for their entire party for the last trip. Thus, the units for expenditures are party trips. Converting visits to party trips assures that the units are the same in the multiplication steps that lead to estimates of total expenditures (visits in party trips times expenditures in party trips).
} 
Table 15. Regional economic impacts of Lake Barkley private dock owners'/users' trip spending (1999, for trip spending within 30 miles only).

\begin{tabular}{|c|c|c|c|c|}
\hline \multicolumn{5}{|c|}{$\begin{array}{l}\text { Summary Results Table } \\
\text { Impacts on Local Economy }\end{array}$} \\
\hline Economic Measure & & Direct & "Multiplier & Total \\
\hline Output/sales (\$MM) & & $\$ 4.37$ & 1.46 & $\$ 6.38$ \\
\hline Total income (\$MM) & & $\$ 1.63$ & 0.52 & $\$ 2.29$ \\
\hline Total value added (\$MM) & & $\$ 2.43$ & 0.81 & $\$ 3.53$ \\
\hline Jobs & & 104.54 & 29.39 & 132.53 \\
\hline \multicolumn{3}{|c|}{ Total visitor spending (\$MM) } & \multicolumn{2}{|l|}{7.28} \\
\hline \multicolumn{3}{|l|}{ Capture rate } & \multicolumn{2}{|l|}{$60 \%$} \\
\hline \multicolumn{3}{|c|}{ Effective spending multiplier } & \multicolumn{2}{|l|}{0.88} \\
\hline \multicolumn{5}{|c|}{ Direct Effects } \\
\hline Sector & Sales (\$MM) & Income (\$MM) & $\begin{array}{l}\text { Value Added } \\
\text { (\$MM) }\end{array}$ & Jobs \\
\hline Lodging & $\$ 0.05$ & $\$ 0.02$ & $\$ 0.03$ & 1.34 \\
\hline Eat and drink & $\$ 1.70$ & $\$ 0.60$ & $\$ 0.84$ & 53.92 \\
\hline Amusement and recreation & $\$ 0.27$ & $\$ 0.11$ & $\$ 0.17$ & 11.36 \\
\hline Retail & $\$ 1.01$ & $\$ 0.49$ & $\$ 0.79$ & 25.00 \\
\hline Wholesale & $\$ 0.28$ & $\$ 0.12$ & $\$ 0.19$ & 3.31 \\
\hline Other services & $\$ 0.38$ & $\$ 0.11$ & $\$ 0.17$ & 4.34 \\
\hline Groceries & $\$ 0.14$ & 0.02 & $\$ 0.04$ & 0.83 \\
\hline Sporting goods & $\$ 0.01$ & $\$ 0.00$ & $\$ 0.00$ & 0.00 \\
\hline Other manufacturing & $\$ 0.49$ & $\$ 0.15$ & $\$ 0.19$ & 4.24 \\
\hline Government & $\$ 0.03$ & $\$ 0.01$ & $\$ 0.01$ & 0.21 \\
\hline Total & $\$ 4.37$ & $\$ 1.63$ & $\$ 2.43$ & 104.54 \\
\hline \multicolumn{5}{|c|}{ Total Effects } \\
\hline Sector & Sales (\$MM) & Income (\$MM) & $\begin{array}{l}\text { Value Added } \\
(\$ M M)\end{array}$ & Jobs \\
\hline Lodging & \$0.07 & $\$ 0.03$ & $\$ 0.04$ & 1.76 \\
\hline Eat and drink & $\$ 1.78$ & $\$ 0.63$ & $\$ 0.89$ & 56.51 \\
\hline Amusement and recreation & $\$ 0.30$ & $\$ 0.12$ & $\$ 0.18$ & 11.98 \\
\hline Retail & $\$ 1.17$ & $\$ 0.57$ & $\$ 0.93$ & 29.54 \\
\hline Wholesale & $\$ 0.41$ & $\$ 0.17$ & $\$ 0.28$ & 4.86 \\
\hline Other services & $\$ 1.42$ & $\$ 0.46$ & $\$ 0.79$ & 17.77 \\
\hline Groceries & $\$ 0.21$ & $\$ 0.04$ & $\$ 0.06$ & 1.34 \\
\hline Sporting goods & $\$ 0.01$ & $\$ 0.00$ & $\$ 0.00$ & 0.00 \\
\hline Other manufacturing & $\$ 0.85$ & $\$ 0.25$ & $\$ 0.32$ & 7.75 \\
\hline Government & $\$ 0.15$ & $\$ 0.03$ & $\$ 0.05$ & 1.03 \\
\hline Total & $\$ 6.38$ & $\$ 2.29$ & $\$ 3.53$ & 132.53 \\
\hline
\end{tabular}


spending. Forty percent leaks out of the local economy to cover the costs of imported goods bought by visitors. ${ }^{1}$

The sales multiplier ${ }^{2}$ for the region is 1.46 , meaning that an additional $\$ 0.46$ in sales is generated through secondary effects for every dollar of direct sales. Secondary effects generate an additional 28 jobs, for a total of 133 direct and secondary jobs (Table 15). Likewise, secondary effects generate an additional \$0.66 million in personal income and \$1.1 million in value added (personal income + proprietor's income + indirect business tax). Roughly 14 direct jobs are supported by each million dollars in total dock user spending. Including multiplier effects, each million dollars in total dock user spending supports about 18 jobs.

The $\$ 1.3$ million in spending on new boats, storage fees, insurance, and repairs/maintenance from Table 14 had a direct economic impact on the region of \$0.76 million in direct sales, \$0.34 million in personal income (wages and salaries), and supported 11 direct jobs in the region (Table 16). The manufacturing sector received the largest amount of direct sales $(\$ 530,000)$, followed by retail $(\$ 130,000)$.

Direct effects only accrue to the industries where dock owner spending is directly received. For example, since no money is spent in the Lodging sector from dock owner annual and durable goods spending, that cell is blank in the top sector of Table 16 (Direct Effects). However, other companies receiving direct payments, e.g. insurance companies may hire employees who live in the region and spend money in the local Lodging sector. Since this is a multiplier (secondary) effect upon the Lodging sector, some amount of sales appears in the Lodging cell in the Total Effects sector of Table 16.

The local region surrounding Lake Barkley captures 57 percent of dock owner spending on new boats and annual services. Forty-three percent leaks out of the local economy to cover the costs of imported boats and services bought by visitors.

1 For example, if a visitor buys $\$ 50$ worth of clothing that is not manufactured in the local region, only the local margins (retail and locally operated wholesale and transportation), say $\$ 30$, will be captured by the local economy as direct sales. The remaining $\$ 20$ will leak immediately outside the local economy to cover the producer price (or price of good at the factory), and non-local margins (wholesale and transportation).

2 Multipliers for the 15-county region are from a 2000 input-output model estimated with the IMPLAN system. 
Table 16. Regional economic impacts of Lake Barkley private dock owners' durable goods and annual spending (1999).

\begin{tabular}{|c|c|c|c|c|}
\hline \multicolumn{5}{|c|}{$\begin{array}{l}\text { Summary Results Table } \\
\text { Impacts on Local Economy }\end{array}$} \\
\hline \multicolumn{2}{|l|}{ Economic Measure } & Direct & Multiplier & Total \\
\hline \multicolumn{2}{|l|}{ Output/sales (\$MM) } & $\$ 0.76$ & 1.50 & $\$ 1.14$ \\
\hline \multicolumn{2}{|l|}{ Total income (\$MM) } & $\$ 0.34$ & 0.62 & $\$ 0.47$ \\
\hline \multicolumn{2}{|l|}{ Total value added (\$MM) } & $\$ 0.42$ & 0.83 & $\$ 0.63$ \\
\hline \multicolumn{2}{|l|}{ Jobs } & 10.85 & 20.82 & 15.80 \\
\hline \multicolumn{3}{|c|}{ Total visitor spending (\$MM) } & \multicolumn{2}{|l|}{1.33} \\
\hline \multicolumn{3}{|c|}{ Capture rate } & \multicolumn{2}{|l|}{$57 \%$} \\
\hline \multicolumn{3}{|c|}{ Effective spending multiplier } & \multicolumn{2}{|l|}{0.86} \\
\hline \multicolumn{5}{|c|}{ Direct Effects } \\
\hline Sector & Sales (\$MM) & Income (\$MM) & $\begin{array}{l}\text { Value Added } \\
\text { (\$MM) }\end{array}$ & Jobs \\
\hline Lodging & $\$-$ & $\$-$ & $\$-$ & - \\
\hline Eat and drink & $\$-$ & $\$-$ & $\$-$ & - \\
\hline Amusement and recreation & $\$-$ & $\$-$ & $\$-$ & - \\
\hline Retail & $\$ 0.13$ & $\$ 0.06$ & $\$ 0.10$ & 2.17 \\
\hline Wholesale & $\$ 0.01$ & $\$ 0.00$ & $\$ 0.01$ & 0.10 \\
\hline Other services & $\$ 0.09$ & $\$ 0.02$ & $\$ 0.03$ & 0.52 \\
\hline Groceries & $\$-$ & $\$-$ & $\$-$ & - \\
\hline Sporting goods & $\$-$ & $\$-$ & $\$-$ & - \\
\hline Other manufacturing & $\$ 0.53$ & $\$ 0.27$ & $\$ 0.30$ & 8.06 \\
\hline Government & $\$ 0.00$ & $\$ 0.00$ & $\$ 0.00$ & 0.00 \\
\hline Total & $\$ 0.76$ & $\$ 0.34$ & $\$ 0.42$ & 10.85 \\
\hline \multicolumn{5}{|c|}{ Total Effects } \\
\hline Sector & Sales (\$MM) & Income (\$MM) & $\begin{array}{l}\text { Value Added } \\
\text { (\$MM) }\end{array}$ & Jobs \\
\hline Lodging & $\$ 0.00$ & $\$ 0.00$ & $\$ 0.00$ & 0.10 \\
\hline Eat and drink & $\$ 0.01$ & $\$ 0.00$ & $\$ 0.01$ & 0.41 \\
\hline Amusement and recreation & $\$ 0.00$ & $\$ 0.00$ & $\$ 0.00$ & 0.00 \\
\hline Retail & $\$ 0.17$ & $\$ 0.08$ & $\$ 0.13$ & 3.20 \\
\hline Wholesale & $\$ 0.03$ & $\$ 0.01$ & $\$ 0.02$ & 0.41 \\
\hline Other services & $\$ 0.29$ & $\$ 0.08$ & $\$ 0.14$ & 2.89 \\
\hline Groceries & $\$ 0.01$ & $\$ 0.00$ & $\$ 0.00$ & 0.00 \\
\hline Sporting goods & $\$ 0.00$ & $\$ 0.00$ & $\$ 0.00$ & 0.00 \\
\hline Other manufacturing & $\$ 0.61$ & $\$ 0.28$ & $\$ 0.32$ & 8.57 \\
\hline Government & $\$ 0.02$ & $\$ 0.00$ & $\$ 0.01$ & 0.21 \\
\hline Total & $\$ 1.14$ & $\$ 0.47$ & $\$ 0.63$ & 15.80 \\
\hline
\end{tabular}


The sales multiplier for the region is 1.50 , meaning that an additional $\$ 0.50$ in sales is generated through secondary effects for every dollar of direct sales. Secondary effects generate an additional 5 jobs, for a total of 16 direct and secondary jobs (Table 16). Likewise, secondary effects generate an additional $\$ 130,000$ in personal income and $\$ 210,000$ in value added (personal income + proprietor's income + indirect business tax). Roughly 8 direct jobs are supported by each million dollars in total dock owner spending for new boats and annual services. Including multiplier effects, each million dollars in total dock owner spending supports about 12 jobs.

\section{Value of 1999 impacts in 2004 dollars}

The 1999 economic impacts reported above were adjusted to 2004 impacts by multiplying 1999 figures by an average consumer price index of 1.21 (U.S. Department of Labor 2006). The results are presented in Table 17.

Table 17. Regional economic impacts of Lake Barkley private dock owners'/users' trip and owners' annual spending (in 2004 dollars, for spending within 30 miles only).

\begin{tabular}{|l|l|l|l|l||}
\hline & \multicolumn{2}{|c|}{$\begin{array}{c}\text { Trip Spending (within } \\
\text { 30 miles) }\end{array}$} & \multicolumn{2}{c||}{$\begin{array}{c}\text { Durable Goods and other } \\
\text { Annual Costs Spent Locally }\end{array}$} \\
\hline \hline Total spending (\$MM) & \multicolumn{2}{|c|}{$\$ 8.81$} & \multicolumn{2}{c||}{$\$ 1.61$} \\
\hline \hline & Direct Effects & Total Effects & Direct Effects & Total Effects \\
\hline Output/sales (\$MM) & $\$ 5.28$ & $\$ 7.72$ & $\$ 0.92$ & $\$ 1.38$ \\
\hline Total income (\$MM) & $\$ 1.97$ & $\$ 2.77$ & $\$ 0.42$ & $\$ 0.57$ \\
\hline Total value added (\$MM) & $\$ 2.94$ & $\$ 4.27$ & $\$ 0.51$ & $\$ 0.76$ \\
\hline \hline $\begin{array}{l}\text { Note: Spending and economic effects in this table are in 2004 dollars, as opposed to the 1999 dollars re- } \\
\text { ported elsewhere in this report. }\end{array}$
\end{tabular}

In 2004 dollars, total private dock user trip spending locally of $\$ 8.8$ million resulted in $\$ 2.0$ million in the region in personal income and $\$ 2.9$ million in value added (personal income + proprietor's income + indirect business tax).With secondary (multiplier) effects, total impacts locally were $\$ 2.8$ million in personal income and $\$ 4.3$ million in value added. There is no change to the number of direct jobs (115) in going from Tables 15 and 16 to Table 17. This is because no new expenditures by dock users are being estimated in Table 17. Instead, expenditures from the 1999 survey are being inflated to 2004 dollars. Since there are no new expenditures, there are no additional jobs being created in 2004. 
After converting annual goods and services to 2004 dollars, the results are $\$ 1.6$ million in private dock owner spending on new boats, storage fees, insurance, and repairs/maintenance. The impacts of annual spending include $\$ 0.4$ million in personal income and $\$ 0.5$ million in value added. With secondary (multiplier) effects, total impacts locally were \$o.6 million in personal income and $\$ 0.8$ million in value added. 


\section{Study Limitations and Error}

The accuracy of the estimates in this report rests on the three inputs: visits, spending averages, and multipliers. The number of trips reported by the sample of private dock owners and the number of boats at the docks are likely the largest potential sources of error.

The multipliers and economic ratios used to convert spending to jobs and income and to estimate secondary effects come from an IMPLAN model for the 15-county region. Although it is difficult to estimate the levels of error, multipliers can vary by about 10 percent between different modeling systems. Multipliers largely influence estimates of secondary effects.

Depending on the direction and magnitude of errors in visits, spending, and multipliers, the different errors may compound or cancel each other. The most important potential errors are in the estimates of total trips. As the model is linear, doubling the amount of visitation will double spending and economic impacts.

In addition to these issues, there are also conceptual issues regarding how much and which spending may be claimed by the project. It is not simple to determine if private dock users would spend their money elsewhere if private docks were not available at Lake Barkley. Furthermore, local visitors are usually excluded in estimating economic impacts, but have been included here. Since they are not a distinct segment, their contribution to the total effects is not readily estimated. However, 62 percent of the dock owners interviewed stated that their permanent residences were within 30 miles of the project. Since around 73 percent of total trip spending occurred within 30 miles of the project, the impact of local spending cannot be ignored.

Only new boat purchases within 30 miles of the project are counted in this analysis. Further, it is assumed that dock maintenance fees and storage fees go primarily to local businesses. However, dock owners were not asked to identify the locations of their insurance companies or boat repair shops. Thus, the extent to which these expenditures accrue to the local economy is not known, but they have been counted as occurring locally (within the 15-county region). 


\section{Summary and Discussion}

Private dock users at Lake Barkley spent $\$ 7.3(\$ 8.8)^{1}$ million in triprelated expenditures and $\$ 1.3$ million ( $\$ 1.6)$ in purchases of new boats and annual services within 30 miles of the lake in 1999. Combining both triprelated and durable expenditures, the direct economic effects of dock user spending were \$5.1 (\$6.2) million in sales, \$2 (\$2.4) million in personal income, \$2.9 (\$3.5) million in direct value added, and 115 jobs. With multiplier effects, created by the recirculation of the money spent by dock users, visitor spending generated a total (direct + secondary) of $\$ 7.5$ (\$9.1) million in local sales, and an associated \$2.8 (\$3.3) million in personal income, $\$ 4.2(\$ 5)$ million in value added, and 148 jobs. Sectors receiving the greatest benefit from private dock users were food and drink, retail trade, manufacturing, and other services. The $\$ 5$ million in direct sales is about 0.9 percent of the total of all tourism activity (568million) (sales have been price inflated for this computation).

Total economic impacts (Tables 15, 16, and 17) are useful for accountability purposes, lake support, and explaining the role of the lake in the region's economy. The REAS model results can also be used to evaluate management alternatives and strategies and to conduct sensitivity analyses. The marginal economic impacts of particular visitor segments are useful for evaluating particular actions. Table 18 shows the changes in sales, jobs, income, and valued added associated with an increase or decrease of 1,000 additional party-trips by each segment. Marginal impact analysis provides answers to the question: "What if?" (reference Foreword).

For example, to evaluate the regional economic impacts of adding an additional 19 private docks, first compute the change in party trips -10 docks produce 538 party trips (average of 53.8 trips per dock per year from Table 3 times 10 docks). That means 19 new docks would produce about 1,000 extra party trips per year. Applying the average spending for the overnight segment in Table 9, the expansion generates an additional $\$ 261,000$ in total trip spending (\$261 per party trip from Table 9 times $1,000)$, $\$ 157,000$ dollars in direct sales in the region, $\$ 58,000$ in personal income, $\$ 87,000$ in value added and 3.8 jobs in direct effects (computed from ratios in Table 15). In 2004 dollars, the extra 1,000 party trips per

\footnotetext{
1 Numbers in parentheses are in 2004 dollars (see Table 17).
} 
year by private dock users would result in $\$ 189,000$ in direct sales in the region and $\$ 70,600$ in direct personal income. ${ }^{1}$ The impact of this alternative could be compared to others.

Table 18. Direct impacts of an additional 1,000 private dock owner party trips by segment, Lake Barkley.

\begin{tabular}{|c|c|c|c|c|c|}
\hline \multirow[b]{2}{*}{ Segments } & \multicolumn{2}{|c|}{ Local } & \multirow{2}{*}{$\begin{array}{l}\text { Personal } \\
\text { Income } \\
\text { (\$) }\end{array}$} & \multirow{2}{*}{$\begin{array}{l}\text { Value } \\
\text { Added } \\
\text { (\$) }\end{array}$} & \multirow[b]{2}{*}{ Jobs } \\
\hline & Spending (\$) & Direct Sales (\$) & & & \\
\hline \multicolumn{6}{|c|}{ (marginal impacts per 1,000 party-trips, in 1999 dollars) } \\
\hline Day use & $\$ 71,948$ & $\$ 43,142$ & $\$ 16,084$ & $\$ 24,051$ & 1.0 \\
\hline Overnight stay & $\$ 261,083$ & $\$ 156,550$ & $\$ 58,365$ & $\$ 87,275$ & 3.7 \\
\hline Small boat & $\$ 122,795$ & $\$ 73,677$ & $\$ 27,468$ & $\$ 41,074$ & 1.8 \\
\hline Medium boat & $\$ 166,599$ & $\$ 99,960$ & $\$ 37,267$ & $\$ 55,726$ & 2.4 \\
\hline Large boat & $\$ 115,847$ & $\$ 69,508$ & $\$ 25,914$ & $\$ 38,750$ & 1.7 \\
\hline \multicolumn{6}{|c|}{ (marginal impacts per 1,000 party-trips, in 2004 dollars) } \\
\hline Day use & $\$ 87,058$ & $\$ 52,201$ & $\$ 19,462$ & $\$ 29,102$ & 1.0 \\
\hline Overnight stay & $\$ 315,911$ & $\$ 189,426$ & $\$ 70,622$ & $\$ 105,602$ & 3.7 \\
\hline Small boat & $\$ 148,582$ & $\$ 89,149$ & $\$ 33,237$ & $\$ 49,699$ & 1.8 \\
\hline Medium boat & $\$ 201,585$ & $\$ 120,951$ & $\$ 45,093$ & $\$ 67,429$ & 2.4 \\
\hline Large boat & $\$ 140,175$ & $\$ 84,105$ & $\$ 31,356$ & $\$ 46,888$ & 1.7 \\
\hline
\end{tabular}

The economic impacts presented in this report document the economic significance of 51,237 private dock owner trips at Lake Barkley in 1999. The impacts will vary from year to year with changes in prices, visitor volumes, the mix of visitors attracted, and other changes in the lake and surrounding communities. The REAS model has built-in procedures to price adjust spending averages over time, so updated figures may be obtained fairly easily, as we have done in this report, if there are not significant changes in visitor use and spending patterns. In the absence of significant structural changes in the local economy, multipliers will be quite stable. The primary input for updating the estimates is visitation, which must take into account any changes in the mix of visitors or their length of stay in the area.

\footnotetext{
1 The number of jobs, 3.7, remains the same in 2004 because Table 18 reflects the marginal impacts of 1,000 additional party trips; since the ratio between sales and jobs remains the same between 1999 and 2004 , the number of jobs per 1,000 additional party trips does not change.
} 


\section{References}

Chang, W. H., D. B. Propst, D. J. Stynes, and R. S. Jackson. 2003. Recreation visitor spending profiles and economic benefit to Corps of Engineers $(C E)$ projects. ERDC/EL TR-03-21. Vicksburg, MS: U.S. Army Engineer Research and Development Center.

Chang, W. H., D. J. Stynes, R. S. Jackson, and D. B. Propst. 2001. U.S. Army Corps of Engineers Recreation Economic Assessment System (REAS). Portland, OR: Poster presentation at National Natural Resources Management Conference, 2001.

Institute for Water Resources (IWR). 2006. OMB approved surveys. IWR Website. Stuart Davis, Subject Matter Expert, IWR, http://www.waterresources.us/inside/products/pub/surveyssearch.cfm?topic =Recreation (accessed July 10, 2006).

Minnesota IMPLAN Group, Inc. 1996. IMPLAN professional social accounting \$ impact analysis software: User's guide. Stillwater, MN: Minnesota IMPLAN Group, Inc.

Minnesota IMPLAN Group. 2000. IMPLAN professional software, analysis and data guide. 2nd ed., Stillwater, MN: Minnesota IMPLAN Group, Inc.

Propst, D. B., D. J. Stynes, W. H. Chang, and R. S. Jackson. 1998. Estimating the local economic impacts of recreation at Corps of Engineers projects - 1996. Technical Report R-98-1. Vicksburg, MS: U.S. Army Engineer Waterways Experiment Station.

U.S. Army Corps of Engineers. 1999. Project operationn-Shoreline management at Civil Works projects. Engineer Regulation 1130-2-406. Washington, DC.

U.S. Army Corps of Engineers. 2006a. Economic impact analysis. Natural Resources Management Gateway, Wen-Huei Chang, Subject Matter Expert, CEERD-EE-E, www.CorpsLakes.us/REAS (accessed July 10, 2006).

U.S. Army Corps of Engineers. 2006b. Lake Barkley, http://www.lrn.usace.army.mil/op/bar/rec/ (accessed July 10, 2006).

U.S. Army Corps of Engineers. 2006c. Natural Resources Management System (NRMS) historical data. Natural Resources Management Gateway, Mike Owen, Subject Matter Expert, CESWF-OD-R. http://CorpsLakes.usace.army.mil/employees/nrms/nrms.html (accessed July 10, 2006).

U.S. Census Bureau. 2006. State and County Quickfacts, http://quickfacts.census.gov/qfd/index.html (accessed April 25, 2006).

USDA Forest Service, Land Between the Lakes, National Recreation Area, www.lbl.org (accessed May 18, 2006) 
U.S. Department of Labor. 2006. Bureau of Labor Statistics, average from 1999-2004, http://stats.bls.gov (accessed April 25, 2006). 


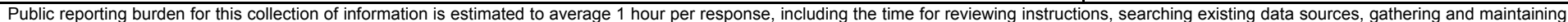

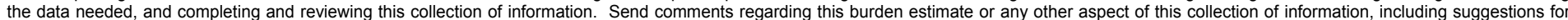

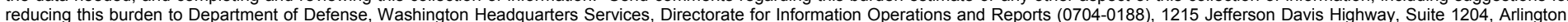

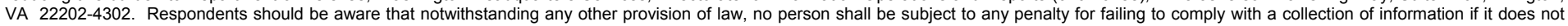
display a currently valid OMB control number. PLEASE DO NOT RETURN YOUR FORM TO THE ABOVE ADDRESS.
1. REPORT DATE (DD-MM-YYYY)
February 2008
2. REPORT TYPE
Final report

4. TITLE AND SUBTITLE

Economic Impacts from Spending by Private Dock Owners at Lake Barkley
3. DATES COVERED (From - To)

5a. CONTRACT NUMBER

5b. GRANT NUMBER

5c. PROGRAM ELEMENT NUMBER

5d. PROJECT NUMBER

5e. TASK NUMBER

5f. WORK UNIT NUMBER

8. PERFORMING ORGANIZATION REPORT NUMBER

ERDC/EL TR-08-8

U.S. Army Engineer Research and Development Center, Environmental Laboratory, 3909 Halls Ferry Road, Vicksburg, MS 39180-6199;

Michigan State University, 115 Natural Resources Building, East Lansing, MI 48824

9. SPONSORING / MONITORING AGENCY NAME(S) AND ADDRESS(ES)

10. SPONSOR/MONITOR'S ACRONYM(S)

11. SPONSOR/MONITOR'S REPORT NUMBER(S)

\section{DISTRIBUTION / AVAILABILITY STATEMENT}

Approved for public release; distribution is unlimited.

\section{SUPPLEMENTARY NOTES}

\section{ABSTRACT}

This report documents the local economic impacts of private dock users at Lake Barkley, located on the border of Kentucky and Tennessee. This economic assessment is based on the results of a 1999 survey of a sample of Lake Barkley private dock owners. Spending estimates are adjusted to 2004 dollars. The economic impacts estimated for Lake Barkley are useful for accountability purposes, lake support, and explaining the role of the lake in the region's economy. This report demonstrates how the survey results can also be used to evaluate management alternatives and strategies and to conduct sensitivity analyses.

\section{SUBJECT TERMS}

Private dock owners

Private docks

Economic assessment

16. SECURITY CLASSIFICATION OF:

Lake Barkley

\begin{tabular}{|l|l|l|}
\hline $\begin{array}{l}\text { a. REPORT } \\
\text { UNCLASSIFIED }\end{array}$ & $\begin{array}{l}\text { b. ABSTRACT } \\
\text { UNCLASSIFIED }\end{array}$ & $\begin{array}{c}\text { c. THIS PAGE } \\
\text { UNCLASSIFIED }\end{array}$ \\
\hline
\end{tabular}

17. LIMITATION OF ABSTRACT
18. NUMBER OF PAGES

50 19a. NAME OF RESPONSIBLE PERSON

19b. TELEPHONE NUMBER (include area code) 